\title{
O CONFLITO SOBRE A SERRA DO GANDARELA uma análise deliberativa sistêmica
}

\section{Filipe Mendes Motta}

E-mail: filipemotta1@gmail.com

(1) Universidade Federal de Minas Gerais (UFMG), Belo Horizonte - MG, Brasil.

DOI: $10.1590 / 3610500 / 2020$

\section{Introdução}

Propomo-nos, aqui, a mostrar que conflito e deliberação não ocorrem em chaves dicotômicas, apontando como, em determinados contextos, o embate e o choque de perspectivas podem ser elementos importantes para a emergência de processos deliberativos. Tomamos como referência de análise a disputa sobre o futuro do território da Serra do Gandarela, em Minas Gerais, que envolve argumentos pela criação da Mina Apolo, pela Vale, e pela implementação, no local, de duas unidades de conservação: o Parque Nacional (Parna) e a Reserva de Desenvolvimento Sustentável (RDS) da Serra do Gandarela. Nossa proposta é reconstituir o processo político observado (2008-2014), por meio da realização de 25 entrevistas com diversos atores envolvidos,

Artigo recebido em: 21/01/2019

Aprovado em: 14/01/2020 tendo como apoio a documentação de licenciamento da mina e de criação do parque e da RDS. Com uma abordagem metodológica interpretativa, operamos a partir da identificação e observação de momentos de interação entre os atores, da manifestação do conflito nesses momentos e das conexóes e fluxos discursivos que atravessam esses diferentes contextos.

O trabalho ancora-se em uma abordagem deliberativa sistêmica. No percurso, explicitamos como o conflito e a deliberação são fenômenos políticos que se atravessam. A análise do caso revela como a agência de atores da sociedade civil, do Ministério Público e da burocracia estatal fomentaram a conectividade entre as diferentes arenas discursivas instauradas em torno do caso, em diálogo com perspectivas contemporâneas que buscam identificar conectores e indutores de sistemas deliberativos (Hendriks, 2016; Mendonça, 2016; Boswell et al., 2016; Faria, 2017; Neblo e White, 2018), apontando o conflito como uma das bases de construção desses sistemas. 
Defendemos que esse processo articulatório atravessado pelo confronto, que é sustentado principalmente pela atuação de um movimento social, contribui para a constituição de um todo deliberativo espraiado no tempo e no espaço. Este todo não é abstrato ou intangível, pois nele vislumbra-se a constituição de um debate público sobre a mineração, os usos de um território, a conservação ambiental e os modos de vida de determinada população. Tal debate se dá por meio de manifestaçóes em espaços públicos, reunióes com comunidades, audiências e consultas públicas e grupos de trabalho; mas também de forma mais abrangente, em uma deliberatividade (Bächtiger e Parkinson, 2019) que resulta das interaçóes nos diversos processos observados no caso - processos nem sempre tidos, em princípio, como deliberativos.

Assim, acreditamos que nosso trabalho traz quatro contribuiçóes para a agenda de pesquisa sobre teoria deliberativa, na medida em que 1) atesta empiricamente, a partir de uma análise normativa, as conexóes entre conflito e deliberação, refutando argumentos recorrentes na teoria política quanto à incompatibilidade entre os dois; 2) reforça a atuação dos movimentos sociais (ativistas e coalização de atores), da burocracia e dos discursos como indutores e conectores de sistemas deliberativos; 3) coloca a necessidade de se pensar na atuação do Ministério Público e do sistema de justiça enquanto atores com potencial para dar ritmo ao funcionamento de processos discursivos na esfera pública, acelerando-os ou pausando-os.

Além disso, 4) operamos uma análise empírica abrangente. A maioria das pesquisas empíricas desenvolvidas no país sob a perspectiva deliberativa tende a fazer recortes, analisando somente partes de determinados subsistemas e enfocando principalmente arenas institucionais de participação, como conselhos e conferências de políticas públicas. Reconhecendo os desafios metodológicos envolvidos, acreditamos que a compreensão adequada dos sistemas deliberativos passa por um acompanhamento sistemático não só das arenas institucionalizadas, mas também pelo entendimento de trocas discursivas entre cidadãos ordinários e organizaçóes da sociedade civil que, ao mesmo tempo, nutrem as discussões dos fóruns formais e são nutridos por eles.
Por fim, e não menos importante, o trabalho analisa um processo político de resistência à expansão da mineração de ferro no estado de Minas Gerais, durante os anos 2000 e 2010, que revela muito sobre as lógicas de ação de atores do Estado, do mercado e da sociedade civil diante das implicaçôes ambientais, sociais e econômicas do boom do setor nesse período. Dada a proximidade geográfica, a coexistência de atores e de arenas, a Questão Gandarela fornece insumos para o entendimento de fenômenos contemporâneos complexos, como os desastres minerários da Samarco (Vale/BHP-Billiton), na bacia do Rio Doce, e da Vale, na mina do Feijāo/Jangada, em Brumadinho e na bacia do rio Paraopeba, bem como de outros conflitos ambientais que têm ocorrido em torno da mineração de larga escala no Brasil.

Dada essa introdução, o artigo está dividido em quatro seçóes: inicialmente faremos uma breve revisão do lugar da teoria deliberativa do qual partimos; na sequência, apresentamos a abordagem metodológica para, então, desenvolvermos a análise do caso, seguida por uma discussão e pelas considerações finais.

\section{Sistema deliberativo}

A teoria deliberativa se estrutura a partir da contribuição de Habermas $(1962,1996,2006)$ com o conceito de esfera pública e a circulação de discursos entre sociedade e núcleos de tomada de decisão política, mediada pela sociedade civil a partir da razão comunicativa. Cabe ao núcleo de decisão política ter discernimento para capturar as demandas em circulação na esfera pública, em seus fluxos selvagens, e a capacidade de transformar as vontades coletivas em decisóes e leis pela via do direito (Habermas, 1996). Após um intenso processo de investimento em pesquisas e experimentos deliberacionistas, observados nos anos 1990 e 2000, tal corrente passou a ser alvo de críticas por focar de forma excessiva os mecanismos institucionais, como minipúblicos, esquecendo-se de refletir sobre a democracia de forma mais abrangente (Chambers, 2009; Parkinson, 2016). Agonistas, teóricos da diferença e feministas acusaram os deliberacionistas de serem responsáveis por uma virada consensualista na teoria democrática a partir dos anos 1990, minando a dimensão conflitiva 
inerente à política. Em nome de uma certa ideologia do consenso, a teoria deliberativa estaria contribuindo para gerar marginalizaçáo - no sentido de apartar determinados grupos da política - e para manter o status quo, impedindo a possibilidade de mudança social (Rancière, 2005; Mouffe, 2005a, 2005b; Miguel, 2013, 2014, 2017; Young, 2005; Trindade, 2018). Nessa visão, a deliberação privilegiaria trocas polidas de argumentos, em exercícios racionais de busca por consenso que eximiriam ou suprimiriam as dimensóes de conflito e confronto da política.

Uma das respostas ${ }^{1}$ às críticas internas e externas vem com o desenvolvimento da ideia de sistema deliberativo. A abordagem sistêmica da deliberação defende um entendimento ampliado dos processos políticos discursivos, englobando desde as conversaçóes realizadas em espaços informais por cidadãos ordinários, até os debates realizados nos e pelos media, passando por atores da sociedade civil e pelas arenas institucionalizadas. A proposta é compreender como os fluxos discursivos circulam por entre esses diferentes espaços, possibilitando transformaçóes de preferências entre os atores envolvidos, a construção coletiva de boas propostas (dimensão epistêmica) e a tomada de decisōes (efetividade). Assim, a deliberação é lida de forma ampliada espacial e temporalmente, transbordando as arenas, que muitas vezes se superpóem e se complementam (Bächtiger e Parkinson, 2019; Dryzek, 2017; Curato, Hammond e Min, 2019).

Atores como a burocracia, os movimentos sociais e os media teriam o potencial de atuar conectando as diferentes pontas de um sistema, ao encadear a circulação discursiva (Mansbridge et al., 2012; Mendonça, 2016; Almeida e Cunha, 2016; Maia, 2012 e 2018). De um modo geral, um sistema deliberativo que funcionasse bem seria capaz de filtrar e descartar as piores ideias sobre problemas públicos que circulam nessa multiplicidade de espaços e temporalidades, adotando e aplicando as melhores delas. Por outro lado, um sistema deliberativo que funcionasse mal distorceria os fatos, retrataria ideias de forma que seus proponentes fossem repudiados e encorajaria cidadãos a adotar modos de agir que não são bons para eles nem para a política (Mansbridge, 1999; Mansbridge et al., 2012).

A ideia de sistema deliberativo não é recente. Explicitada por Mansbridge (1999), tem vários de seus elementos presentes já na obra de Habermas (1996; 2006) e foi retomada algumas vezes ao longo da década passada, o que colocou essa corrente como a principal frente de debates e pesquisas da área (Goodin, 2005; Parkinson, 2006; Hendriks, 2006a e 2006b). No entanto, nos últimos anos têm ganhado corpo definiçóes teóricas mais elaboradas (Dryzek, 2010; Miola, 2012; Mendonça e Maia, 2012; Mansbridge et al., 2012; Dryzek, 2017; Mendonça, 2016; Bächtiger et al., 2018; Bächtiger e Parkinson, 2019; Curato, Hammond e Min, 2019). São raros, no entanto, os estudos empíricos que operacionalizem a aplicação da teoria, ${ }^{2}$ principalmente em contextos do Sul global. Nesse caminho, Warren (2017) defende a abertura da deliberação a contribuiçôes e análises de contextos e práticas políticas não compreendidos, em princípio, como deliberativos, e Dryzek (2017) aponta que um dos caminhos necessários para o amadurecimento da discussão de sistemas passa pela retomada de uma compreensão abrangente da esfera pública, conceito abandonado por analistas e teóricos nos últimos anos. São esses caminhos que pretendemos trilhar neste trabalho.

Assim, nossa leitura opera num movimento que vê a deliberação, empiricamente, em processos de participação política abrangentes, que extrapolam os espaços institucionais (Mansbridge, 1999; Dryzek, 2000). Por isso, consideramos a açáo coletiva e o conflito, em suas diferentes formas, como passíveis de diálogo com a deliberação. Numa via de mão dupla, o confronto político e seus repertórios de ação fomentam processos de deliberação pública; ao mesmo tempo, a deliberação pública, ao possibilitar a visibilidade de questôes sociais sensíveis, tem o potencial de desencadear confrontos (Mendonça e Ercan, 2015; Knops, 2007; Felicetti, 2018; Hendriks, 2006a, 2006b; Dodge, 2014). ${ }^{3}$ Por fim, este trabalho segue a trilha de valorizaçâo do entendimento da dimensão contextual e contingente na análise de processos deliberativos, o que exige a compreensáo atenta dos atores e dos espaços observados (Bächtiger e Parkinson, 2019) e também das relaçóes entre poder e deliberação, reconhecendo as assimetrias entre os atores envolvidos e os impactos para o processo (Curato, Hammond e Min, 2019). 


\section{Metodologia}

Como dito, faremos uma análise fundada numa abordagem metodológica interpretativista, não causal. Dessa forma, seguimos as orientaçóes de Boswell e Corbett (2017) e Ercan e colaboradores (2015), para os quais, dada a complexidade, porosidade e natureza cambiante dos sistemas deliberativos, a compreensão deles dependerá de análises densas, que extrapolam as abordagens quantitativas de mensuração de qualidades deliberativas. Para esses autores, é preciso olhar "para as sobreposiçóes e interaçóes entre os espaços que possibilitam e sustentam, ou minam e desafiam, as normas e bens mais amplos associados à democracia deliberativa" (Boswell e Corbett, 2017, p. 802). ${ }^{4}$ Também afirmam que "pesquisadores que adotam uma abordagem conscientemente interpretativa estáo mais bem posicionados para conciliar o empírico e o normativo" (Boswell e Corbett, 2017, p. 808).

Tomaremos como referência na estruturação da análise a formulaçáo de sequência de momentos deliberativos de Goodin (2005). Ele propóe romper com uma visão "unitária" da deliberação, focada somente em um ator/arena, e ir além do two-track mode $\overline{~ h a b e r m a s i a n o, ~ f u n d a d o ~ n a ~ a l i m e n t a c ̧ a ̃ o ~}$ dos corpos representativos por uma esfera pública discursivamente estruturada. A formulação de Goodin é construída no nível institucional, considerando o parlamento, mas avança ao sugerir que diferentes atores políticos podem dividir a tarefa de exercer a deliberação sem que sejam exigidos de todos os mesmos padróes deliberativos. Seguindo o argumento do autor, a divisão de tarefas entre as diferentes fases de um processo, por exemplo, seria fundamental para a construção de uma deliberação que emerge do todo. Assim, mais do que pensar em práticas individualizantes e específicas de deliberação, é preciso observar como esta aparece em processos, fomentada por provimentos públicos de razóes e escutas engajadas ${ }^{6}$ (Bäthiger e Parkinson, 2019).

Ainda que, normativamente, o conceito de momentos deliberativos de Goodin não seja visto como o ideal, ${ }^{7}$ ele possibilita ampliar as aplicaçōes empíricas da deliberação. Numa discussão política, a própria definição do que é o problema a ser discutido é, tipicamente, algo em jogo, não fixado a priori; por isso é preciso ter em mente que os atores políticos raramente deliberarão compartilhando ideias sobre como solucionar uma questão (Goodin, 2005, p. 182-183 e p. 186). Assim, o conflito é algo permanente. A forma como a deliberação se manifesta nos diferentes espaços não é igual; nem tampouco se pode exigir as mesmas virtudes deliberativas em diferentes momentos e arenas em que a deliberação se manifesta, ele aponta. Assim, Goodin abre espaço para diferentes formas de se fazer política dentro da lógica deliberativa, como já posto - um movimento defendido recentemente também por Warren (2017) e por Bächtiger e Parkinson (2019). Aqui, extrapolamos a formulação de Goodin para um contexto mais amplo, sem delimitaçóes rígidas entre as diferentes arenas de debate e de conflito, como proposto por formulaçóes posteriores de sistema deliberativo (Mansbridge e Parkinson, 2012) - que não haviam, no entanto, apontado caminhos metodológicos para trabalhos empíricos.

Assim, é a partir do conceito de sequência de momentos deliberativos que procuramos estruturar essa análise de reconstituição de um contexto político confrontacional. Como adiantado, buscamos reconstruir o processo político da Questáo Gandarela e identificar os momentos que o compóem por meio da realizaçâo de entrevistas semiestruturadas com os atores-chave envolvidos e da análise de documentos relacionados ao caso.

Buscou-se representar, entre os entrevistados, todos os grupos de atores envolvidos. ${ }^{8}$ As 25 pessoas entrevistadas foram escolhidas a partir de conversas preliminares com representantes do Movimento pela Preservaçáo da Serra do Gandarela e apoiadores do projeto da mina. Os próprios atores foram apontando outros que poderiam contribuir para o andamento da pesquisa, entre os variados grupos.

A partir das conversas, chegamos à nossa sequência de momentos deliberativos: 1) a apresentação do projeto de mineração de ferro conhecido como Projeto Apolo pela Vale às comunidades do entorno da Serra do Gandarela, em 2007 e 2008'; 2) a projeção pública da questão, a partir da articulação de atores da sociedade civil em resistência ao projeto minerador, no que viria a se constituir como Movimento pela Preservação da Serra do Gandarela, resultando na proposta de um parque nacional, em 2009; 3) as audiências públicas de 
licenciamento da Mina Apolo, em 2010; 4) a criação de dois grupos de trabalho pelos governos federal e estadual (MG) para construir uma saída para o impasse entre os projetos da mina e do parque, em 2009 e 2010; 5) a realizaçáo de consultas públicas sobre a implementação do Parque Nacional da Serra do Gandarela e de reunióes do Instituto Chico Mendes (ICMBio) com as comunidades do entorno da serra para debater o projeto da unidade de conservação, a partir das quais surge a proposta de uma Reserva de Desenvolvimento Sustentável (RDS) contígua ao Parque, em 2011; 6) o decreto de criação do Parque Nacional da Serra do Gandarela, pela Presidência da República, em 2014.

Detalharemos esses momentos a seguir, após breve explicação do contexto. ${ }^{10}$ Mais uma vez, é preciso reforçar que, como em Goodin, e como defendido em outras formulaçōes recentes sobre sistemas deliberativos, $a$ compreensão do todo deliberativo ficará explícita ao se tomar o processo por completo, ainda que alguns desses momentos também revelem práticas deliberativas individuais. Caso contrário, teremos apenas um amontoado de microanálises, ou um conjunto de fóruns emparelhados, parafraseando Bächtiger e Parkinson (2019), para os quais a deliberação precisa ser tomada pela escala e complexidade de um sistema, e não apenas por ingredientes institucionalizados inseridos num ecossistema político. ${ }^{11}$

\section{Análise dos momentos deliberativos}

A Serra do Gandarela está localizada na regiáo central de Minas Gerais, no interior do Quadrilátero Ferrífero, um dos principais polos de extração mineral do mundo. Curiosamente, devido ao difícil acesso, é também um dos últimos redutos de Mata Atlântica preservada do estado, sendo ocupada por pequenas comunidades rurais. Próxima à capital Belo Horizonte, a serra se estende por um conjunto de municípios com histórico minerador, como Santa Bárbara, Caeté, Raposos, Barão de Cocais e Rio Acima, na mesma região, além de outros centros mineradores conhecidos, como Ouro Preto e Mariana, e das serras do Caraça e da Piedade, ecossistemas relevantes da Serra do Espinhaço e importantes destinos turísticos de Minas Gerais. O Gandarela é rico em cangas ferruginosas, formação geológica porosa que facilita a existência de aquíferos significativos tanto para rios da bacia do rio Doce quanto para a bacia do rio das Velhas, maior afluente do São Francisco. Ao mesmo tempo, as cangas têm alta concentraçáo de ferro, $o$ que as torna objeto de interesse das mineradoras. É nesse cenário que nossa análise se desenvolve.

\section{A chegada: apresentação do projeto de mineração às comunidades}

O aparecimento público da Questão Gandarela se deu em três espaços: reunióes abertas com comunidades, conselhos municipais de meio ambiente e o conselho consultivo de uma área de proteçáo ambiental. Em todos, houve grande animosidade, bate-bocas e discussōes acaloradas entre moradores, ambientalistas e os representantes da Vale que apresentavam o projeto de mineração.

Em Santa Bárbara, a emergência da questão se deu fora dos ritos institucionalizados dos conselhos. A diretoria da Vale pousou de helicóptero na pequena comunidade de André do Mato Dentro ${ }^{12}$ num fim de semana de 2007, e fez uma reunião com algumas dezenas de moradores no gramado ao lado da igrejinha local. Além da diferença social e econômica entre os dois conjuntos de atores envolvidos, explicitados pela presença da aeronave, dois argumentos estruturantes do debate, operados na maior parte do tempo em chaves antagônicas e que permaneceriam candentes durante todo o processo, foram expressos na ocasiáo: 1) a ameaça da mineração aos recursos hídricos da região do Gandarela e 2) o potencial de criação de empregos em decorrência da atividade.

Além do medo de uma parcela da população de ter os cursos de água prejudicados, e por estar diante de um interlocutor poderoso, o anúncio do projeto minerador produziu outras reverberaçōes na localidade. Fez, por exemplo, com que líderes comunitários procurassem contato externo com outros grupos preocupados com os impactos da atividade mineradora na região, o que contribuiria para a entrada de alguns ambientalistas de Caeté ${ }^{13}$ no debate.

É importante destacar que havia na comunidade do André, a partir dos anos 1990, um histórico de 
participação na associação comunitária local, o que contribuiu para o fomento dos debates. A partir da chegada da Vale, a comunidade passa a incluir a pauta e o debate da mineraçáo na Serra em suas reunióes, muitas delas agendadas exclusivamente para discutir o assunto. Nas reunióes e na vida cotidiana, o empreendimento marcou uma clivagem entre aqueles que viam a chegada da mineração como ameaça e aqueles que a encaravam como oportunidade de emprego, argumento presente sobretudo na fala dos mais jovens.

No entanto, como pontua uma das lideranças do André do Mato Dentro - que viria a integrar o Movimento pela Preservação da Serra do Gandarela -, todos esses confrontos trouxeram uma série de consequências. Uma delas foi a ampliação do conhecimento e do entendimento da comunidade sobre o que é a serra que a rodeia, o que remete ao caráter epistêmico da deliberação, de expansão do entendimento sobre questôes a partir de discussóes coletivas (Chambers, 2017; Landemore, 2013).

As comunidades pensavam a Gandarela como o topo da serra. Não pensavam como uma coisa maior, o sinclinal ${ }^{14}$ Gandarela. Depois disso que a gente passou a se dizer Gandarela. Faz parte desse conceito de entender a Gandarela (Entrevista 2, 14 de março de 2015).

Em Caeté, no mesmo ano de 2007, membros do Conselho Municipal de Meio Ambiente passaram a ouvir rumores sobre o interesse da Vale em abrir "a maior mina a céu aberto do mundo" na cidade, como conta outra integrante do Movimento, à época conselheira do órgão. Avaliando que o projeto viria a ser debatido no fórum, alguns conselheiros foram à Fundação Estadual de Meio Ambiente de Minas Gerais (Feam) pesquisar processos de licenciamento ambiental e encontraram pedidos de Autorização Ambiental de Funcionamento (AAF) ${ }^{15}$ da Vale para mineração no território da serra. Em 2004, uma empresa chamada Mineração Estrela de Apolo havia pedido a condiçáo de conformidade da prefeitura de Caeté para operar no Gandarela. No entanto, o pedido havia sido barrado pelo Conselho Municipal de Meio Ambiente, sob a justificativa de que o empreendimento colocaria em risco o futuro da cidade por ameaçar seus recursos hídricos. A mineração Estrela de Apolo foi incorporada pela Vale, dando base ao projeto Apolo. Após um manifesto de autoria de lideranças comunitárias de André do Mato Dentro, o SOS Serra do Espinhaço, ser disseminado pela internet, esses moradores se articulariam com o grupo de Caeté e outro de Rio Acima, dando origem ao Movimento Pela Preservação da Serra do Gandarela.

Já no caso de Rio Acima, relatos de integrantes do Movimento afirmam que o conflito entre a empresa e ambientalistas começou porque a Vale omitira-se sobre o real impacto do empreendimento pretendido para a região, informando que o município não seria impactado diretamente pela mina. $\mathrm{Na}$ mesma época, porém, a mineradora buscava o aval do conselho consultivo da APA-Sul, ${ }^{16}$ que engloba parte substantiva da serra do Gandarela, para a abertura do empreendimento, e o documento que apresentara apontava áreas de pesquisa em Rio Acima.

Por fim, as lideranças de outra comunidade afetada pelo projeto, o município de Raposos, entrariam posteriormente no Movimento pela Preservação da Serra do Gandarela. Raposos foi notificada pela Vale de seu interesse em atuar na regiáo também a partir de reunióes realizadas pela empresa com a comunidade em 2008 e 2009. A principal controvérsia, no caso desse município, era a construção da barragem de rejeitos do empreendimento minerador, prevista para ser feita no Ribeirão da Prata, curso d'água que nasce na Serra, deságua no Rio das Velhas, em Raposos, e atravessa parte de sua área urbana. ${ }^{17}$ Pelo projeto original da Mina Apolo, a barragem de rejeitos de Raposos ficaria a oito quilômetros da cidade. Assim como em André do Mato Dentro, o argumento da geração de empregos apareceu como o discurso apaziguador, enaltecendo os benefícios da chegada da empresa.

O grupo de Raposos acabaria se articulando como o Movimento Contra a Barragem de Rejeitos em Raposos. A união das ações de mobilização do grupo com o Movimento pela Preservação da Serra do Gandarela só se daria depois, por discordâncias na estratégia de posicionamento diante do empreendimento.

O que a emergência da Questão Gandarela aponta? $\mathrm{O}$ conflito e a deliberação pública irrompem 
conjuntamente, num contexto marcado pela assimetria de poder e de informaçóes entre os atores sobre o que estava em jogo e pela baixa reciprocidade entre os grupos de atores envolvidos. Para Habermas (2012), atos de fala portam três pretensóes de validade: 1) as pretensóes de verdade estão em diálogo com o mundo objetivo; 2) as de correção, com o mundo social; e 3) as pretensóes de sinceridade, com o mundo subjetivo. Um ato de fala pode ser questionado pela negação de uma ou mais pretensôes de validade. É por meio da negação das pretensóes de validade que, enquanto sujeitos e sociedade, refletimos e reconstruímos reflexivamente os mundos objetivo, social e subjetivo. Nesse primeiro momento da análise do caso Gandarela, há a negação de uma pretensão de validade recorrente ao longo do conflito ("a mineração é benéfica para a região, pois gera emprego e desenvolvimento econômico"), com base em outro padrão de entendimento ("a mineração precisa ser analisada criticamente, na medida em que pode trazer danos ambientais irreversíveis para a regiáo"). Ou seja, nesse caso, o conflito de entendimentos sobre um determinado tópico foi fundamental para que ele se tornasse tema de escrutínio público. Escrutínio esse que continuaria ocorrendo e se desdobrando em outros momentos.

\section{$O$ sinal amarelo: projeção pública e um segundo não ao projeto Apolo}

A primeira ação confrontacional conjunta do grupo de resistência em defesa do Gandarela aconteceu com o acionamento do Ministério Público Federal e do Ministério Público Estadual na tentativa de barrar o licenciamento fracionado e simplificado do empreendimento da Vale pelas Autorizaçóes Ambientais de Funcionamento (AAFs), que reduziriam os trâmites do processo, inclusive sem exigir a realização de audiências públicas para debater o projeto.

Losekann (2013, p. 312) pontua que, muitas vezes, o acionamento do Ministério Público por movimento sociais ambientalistas se relaciona à dificuldade de abertura, por parte de instituições representativas e participativas, para atender às demandas dos grupos quanto às instâncias representativas, "principalmente quando ameaçam poderes econômicos com vínculos fortemente estabelecidos no sistema político brasileiro"
(Losekann, 2013, p. 312). A judicialização, dessa forma, pode ser tida tanto como um processo de crítica institucional quanto como algo que pode gerar incrementos democráticos. Isso faz do Ministério Público Federal e do Ministério Público Estadual coprotagonistas da causa.

No caso Gandarela, ainda que respaldadas por preceitos jurídicos, as Açôes Civis Públicas (ACPs) dos órgãos amplificaram institucionalmente as vocalizaçóes do Movimento: 1) de que o licenciamento da mina Apolo não deveria ser feito via Autorização Ambiental de Funcionamento (AAF); 2) de que os licenciamentos na região da Serra fossem suspensos até a conclusão do projeto do parque; e 3) de que o ICMBio fosse mais ágil no andamento do projeto da unidade de conservaçấo. O MP se tornou um canal por meio do qual o movimento social falava com o Poder Executivo, convocando-o a agir diante de determinado tema pelo qual ele deveria se responsabilizar. Agiu, dessa forma, como um ator que abriu as comportas do Estado para discussóes oriundas da esfera pública, para usar concepçóes habermasianas, ou como conector de um processo deliberativo (entre sociedade e Estado), para usar terminologias contemporâneas (Mendonça, 2016; Boswell et al., 2016; Hendriks, 2016). Os enunciados das Açóes Civis Públicas carregavam elementos dos discursos do Movimento, ainda que parcialmente ressignificados. ${ }^{18}$ É importante pontuar que, todas as vezes que essas falas eram vocalizadas, o discurso que o Movimento queria imprimir era, ainda que indiretamente, de restrição ao Projeto Apolo.

Em 2009, quando a Vale lança o projeto Apolo de forma mais abrangente, não mais utilizando as AAFs, o Movimento pela Preservação da Serra do Gandarela já tinha uma composição mais bem definida. Reunindo-se quase semanalmente, adotou uma série de ações que deram projeção pública ao problema que identificara: o projeto de mineraçáo na serra. $\mathrm{O}$ grupo passou a circular um abaixo-assinado contra o projeto minerador, colhendo assinaturas em vias públicas das cidades, a fazer manifestaçōes nas ruas - principalmente em Caeté e Belo Horizonte-, a dar palestras em escolas e empresas, e a publicar artigos em jornais.

A negativa à pretensão da Vale de minerar a Serra ganhou projeção a partir da articulação 
entre diferentes atores sociais, na constituição de um movimento que buscou dar visibilidade à causa por meio dessas manifestaçóes públicas, de articulaçóes junto ao Ministério Público Federal e Estadual e do entendimento de que a comunidade teria o "direito de dizer não" ao projeto minerador desenvolvimentista, expressão presente na fala de alguns membros do Movimento e em algumas peças de comunicação contra o projeto Apolo. ${ }^{19}$ Todo esse processo explicita, na esfera pública, o conflito ambiental existente, e projeta argumentos a serem mobilizados na relaçáo com atores do Estado e com as comunidades afetadas.

Nessa chave, é interessante a leitura de Laclau e Mouffe (2015, p. 198-204), para os quais o antagonismo é a negação de uma dada ordem por meio da exposiçáo dos limites dessa ordem, rompendo fixaçóes. Não se trata da posição congelada "na qual os polos do antagonismo constituiriam casos parciais [...] objetivos" (p. 204). O antagonismo não se reduz à oposição entre os polos, afirmam. $\mathrm{O}$ antagonismo, apontam os pensadores, é o questionamento dos limites do social a partir de dentro do próprio social, como forma de destruir ambições de presenças plenas e totalizantes. $\mathrm{O}$ antagonismo que se baseia na negação da mineração busca romper com as fixaçóes de uma ordem social hegemônica, fundada no neoextrativismo brasileiro dos anos 2000; e, de dentro dessa mesma ordem, projetar outras possibilidades, que são também contingentes na teoria e na prática, como veremos.

Em diálogo com Carolyn Hendriks (2006a e 2006b), e preocupada com a atençáo dada pela teoria deliberativa às organizaçôes da sociedade civil, Jennifer Dodge (2014) busca olhar para as contribuiçóes, para o sistema deliberativo, de controvérsias geradas pelas organizaçóes da sociedade civil. Observando especificamente as questóes ambientais, a autora afirma que os movimentos sociais constroem tanto "narrativas sobre questôes ambientais quanto processos deliberativos para moldar a formulação de políticas" (Dodge, 2014, p. 161). As narrativas construídas pelos movimentos, aponta Dodge, buscam:

1) definir ou alterar os riscos ambientais debatidos na agenda pública; 2) construir o formato da deliberação pública, alterando as regras do jogo;
3) construir o conteúdo da deliberação pública, formatando significados relacionados à política ambiental e, 4) alinhar os fóruns, arenas e tribunais integrantes do sistema (Dodge, 2014, p. 163). ${ }^{20}$

$\mathrm{O}$ argumento de Dodge é de que olhar a deliberação como forma de construção de políticas públicas envolve compreendê-la como uma contestaçáo dos significados das políticas existentes e de seus processos de construção por parte da sociedade civil (Dodge, 2014, p. 162). Nesse sentido, a estratégia de atuação do Movimento avança de forma "propositiva" com o projeto de criação do Parque Nacional da Serra do Gandarela (uma intervenção em política pública), apresentado ao ICMBio em 2009. Isso não significa que se tenha optado por uma estratégia não-confrontacional: a possibilidade de existência da Unidade de Conservação significava, em tese, a impossibilidade de se minerar na área e a sustentação do conflito com os interesses mineradores. Temos, assim, duas linhas argumentativas fortes e complementares colocadas pelo Movimento na esfera pública, provendo-a de razóes e promovendo deliberatividade: 1) de que o projeto de mineração não deveria ser permitido, por ameaçar gravemente o ecossistema da regiāo, incluindo o abastecimento de água e a existência de uma comunidade (Raposos fica abaixo da barragem de rejeitos projetada inicialmente para a Mina); e 2) a de que os atributos ambientais da Serra do Gandarela são de tal importância que a região deve ser transformada em um parque nacional. O movimento social, dessa forma, atuou como provedor de razóes para a deliberação pública, ao mesmo tempo em que sustentava posiçóes adversariais e confrontacionais.

Quando essas novas questôes foram levantadas nos municípios, farpas começam a ser trocadas. Em Caeté, por exemplo, defensores do projeto minerador acusaram os ambientalistas de "forasteiros que não querem o desenvolvimento da cidade", em alusão ao fato de parte do grupo ser de Belo Horizonte e de uma das integrantes ser de origem angolana. Esses elementos reforçaram, assim, um amplo processo deliberativo confrontacional. Esse processo adversarial se acentua com as audiências públicas do licenciamento da Mina Apolo que ocorreram em seis municípios afetados pelo projeto, em 2010, como veremos a seguir. 


\section{O sinal vermelho: as audiências públicas do Projeto Apolo e do Parna}

Em 2009, em uma etapa necessária para o licenciamento do Projeto Apolo, que tramitava nos órgáos estaduais, a Vale realizou seis audiências públicas. ${ }^{21}$ Nelas, o empreendedor fazia a exposiçẫo do projeto, que era seguida de uma explanação dos órgãos do Estado. A partir daí eram abertas inscriçôes para os presentes se manifestarem, com acesso livre. A avaliação da literatura brasileira sobre o papel das audiências como mecanismo de participação social no processo de implementação de grandes empreendimentos é crítica ao mecanismo, visto em boa parte das vezes como protocolar, sendo as colocaçóes dos atores presentes ignoradas nas etapas posteriores de licenciamento (Zhouri et al., 2005; Acselrad, 2010). Apesar dessas fragilidades, no entanto, representantes do Movimento consideraram os encontros como estratégicos para dar visibilidade à questão em debate e projetar publicamente argumentos sobre o conflito em questão. Em sequência e pensadas em conjunto, seguindo o argumento de Goodin (2005), esses espaços institucionalizados compuseram um quadro deliberativo significativo, corroborando o argumento de que é preciso refletir sobre o papel e o potencial dos desenhos e regras institucionais na conexáo de sistemas (Faria, 2017; Hendriks, 2016; Niemeyer e Jennstal, 2018). Como lembrado por Faria (2017, p. 10), "embora as regras apresentem a capacidade de predizer os comportamentos, elas não os substituem". E no caso Gandarela, as limitaçôes das audiências não significaram, necessariamente, uma acomodação $a$ priori dos atores frente ao modelo de participação.

Todas as audiências foram realizadas no período noturno, durante a semana, em espaços na regiāo central dos municípios afetados; em Santa Bárbara, por exemplo, a mais de trinta quilômetros de algumas das comunidades diretamente afetadas. $\mathrm{Na}$ fala dos entrevistados, os encontros em Caeté (o primeiro), Raposos (que contou com a presença ostensiva da segurança da Polícia Militar) ${ }^{22}$, Santa Bárbara e Belo Horizonte foram os mais lembrados quanto ao aspecto confrontacional. De todo modo, as audiências registraram o primeiro momento em que todo o conjunto de atores envolvidos com a Questâo Gandarela se encontraram presencialmente: ambientalistas, moradores dos municípios, empreendedores, políticos locais e técnicos ambientais.

Um integrante do Projeto Manuelzáo e do Movimento, fez a seguinte avaliação da audiência em Caeté:

o empreendedor começou a falar, [depois] a gente pediu a palavra e fomos falar de uma ideia de preservação - enquanto os caras iam falar numa ideia de como se ganhar economicamente com o projeto e tal... E como achei que o clima fosse muito favorável ao investimento, nos causou surpresa quando, ao final da fala, o pessoal aplaudiu a fala da preservação. Então eu falei "olha, isso [a mineração] não é um consenso". É muito difícil você derrubar esses megaempreendimentos porque, às vezes, eles têm, por uma questão de cooptaçāo, às vezes um forte componente político, uma mobilizaçáo social muito forjada em cima disso. Pensei "no final da minha fala eu vou ser vaiado aqui nesse negócio". E foi exatamente o contrário (Entrevista 7, 22 de maio de 2015).

Um ponto que merece atençáo nessa fala é a possibilidade da exposição da diferença desconstruir um suposto consenso que paira sobre um tema, quando as divergências náo aparecem por medo ou desconfiança. Aliás, a percepção do dissenso em relação ao tema possibilitou a ampliaçáo da argumentaçáo sobre a questão e, ao mesmo tempo, do confronto de perspectivas sobre ela, como também observam Mendonça e Ercan (2015) ao analisar manifestaçóes no Brasil e na Turquia sob a perspectiva deliberacionista. Nas entrevistas com moradores e políticos, algumas vezes deparamo-nos com a percepção de que a mineração seria parte constitutiva da natureza econômica e social da região, algo que não poderia ser negado, como uma ideia aceita por todos, consensuada de forma tácita nos municípios. Por isso, discutir o tema por vezes é motivo de embaraço. Em dois momentos do trabalho de campo desta pesquisa, por exemplo, estivemos com moradores de comunidades que demonstraram receio e se recusaram a se posicionar sobre a questão. A situação em Caeté relatada pelo integrante do Projeto Manuelzáo aponta para o potencial que a 
publicidade do posicionamento divergente tem de expor esses falsos consensos.

Além da audiência de Caeté, somente mais uma, em Rio Acima, estava prevista inicialmente nos trâmites do licenciamento da Mina. A partir de conversas de membros do Movimento com o entáo secretário estadual do Meio Ambiente, José Carlos Carvalho, ${ }^{23}$ porém, decidiu-se pela realização de mais quatro eventos em outros quatro municípios: Ouro Preto, Nova Lima, Raposos, Santa Bárbara e Belo Horizonte. Apesar da grande limitação do desenho institucional ser reconhecida pelos atores envolvidos no processo, presente na fala tanto do Movimento como do ex-secretário, a realização das novas audiências foi considerada estratégica pelo Movimento como forma de ampliar o debate público nos municípios afetados e de prover razóes sobre a questão. $\mathrm{O}$ entendimento era de que quanto mais pessoas soubessem do empreendimento, maiores as chances de ele ser barrado - novamente, uma tentativa de fomentar o debate público amarrada a um gesto confrontacional.

Os defensores do projeto minerador, por outro lado, questionaram o aumento do número de encontros, e sobretudo aquele que viria a ser realizado em Belo Horizonte, que não estava na área de influência direta da Mina Apolo, mas poderia ter o abastecimento de água futuro comprometido por alterações nos aquíferos da serra. Como resultado dos debates das audiências, algumas decisóes importantes foram tomadas pelo Estado. A Secretaria de Meio Ambiente solicitou à Vale a elaboração de alternativas à construção da barragem de rejeitos no leito do Ribeirão da Prata e o Ministério Público Estadual recomendou a suspensão do processo de licenciamento do empreendimento até que o projeto do Parque Nacional da Serra do Gandarela, àquela altura já em tramitação no ICMBio, fosse concluído. E, novamente, a força do Ministério Público enquanto indutor de açóes que deram continuidade ao processo (no caso, barrando momentaneamente o licenciamento) foi acentuada, como aponta o depoimento de um técnico do ICMBio:

Houve uma intervenção muito forte do Ministério Público, que recomendou que todos os processos de licenciamento fossem suspensos até a conclusão dos estudos de criação da Unidade de Conservação (UC). Isso foi mais uma deliberação do MP do que uma recomendação nossa [ICMBio]. A gente informou que existia uma proposta e que a gente precisava sentar e discutir - tanto a UC como a mineração. Mas aí o MP recomendou a suspensão e isso foi acatado pela Supram [Superintendência Regional de Meio Ambiente] (Entrevista 24, 4 de novembro de 2015).

A proposta do parque nacional surge a partir de uma dissertação de mestrado em Geografia (Lamounier, 2009) que propunha a criação de um mosaico de unidades de conservação, sobretudo pela região do Gandarela ser uma das últimas áreas com formaçóes ferruginosas com cangas preservadas no estado. Além desse trabalho, foram mobilizados outros estudos, boa parte realizados por pesquisadores da UFMG, que observavam aspectos como a grande incidência de cavidades e sítios arqueológicos e a presença de Mata Atlântica e de mamíferos de grande porte ameaçados de extinção. A decisão do Movimento de submeter a criaçáo da unidade ao Instituto Chico Mendes de Biodiversidade, um órgão federal, foi estratégica. Como o licenciamento ambiental da mina Apolo se encontrava em andamento no Sistema Estadual de Meio Ambiente, e o governo de Minas tinha grandes interesses econômicos no empreendimento, haja vista a presença e a fala do então governador Aécio Neves (PSDB) no lançamento do projeto da Vale, ${ }^{24}$ a avaliação do Movimento era de que a proposta da unidade de conservação não teria chances de sobrevida na administração estadual. ${ }^{25} \mathrm{O}$ projeto foi acolhido pelo ICMBio, que iniciou uma série de estudos para o reconhecimento do território e para atestar a relevância da criação do parque.

É importante frisar que, nesse momento, ainda que uma parcela da população das comunidades estivesse interessada nas possibilidades de emprego relacionadas à implementação da mina, um grande número de moradores assinou o abaixo-assinado pela criaçáo do parque, entendendo que, com ele, atividades na área comum da serra (apicultura, coleta de musgo etc.) não seriam prejudicadas. Essa adesão à proposta do parque sugere a possibilidade de reflexividade ou transformação de preferências, 
por parte da população, que advém dos debates públicos envolvidos no confronto político sustentado nas açôes de mobilizaçáo do Movimento (palestras, passeatas, panfletagem, produção de jornais etc.) e nas audiências.

\section{O estopim: grupos de trabalho}

Dois grupos de trabalho foram criados, por iniciativa do governo de Minas Gerais, com o objetivo de conciliar as propostas de criação do Parque Nacional da Serra do Gandarela, em tramitaçáo no ICMBio, e da mina Apolo, cujo licenciamento, como vimos, havia sido suspenso por determinaçáo do Ministério Público após as audiências públicas. A proposta do governo do estado, agora já sob o comando de Antonio Anastasia (PSDB), era ajustar os desenhos do projeto do parque nacional e da mina Apolo de modo a compatibilizar os dois "empreendimentos".

O primeiro grupo de trabalho, realizado em 2011, teve duração de dois dias, com participação restrita a técnicos do Sistema Estadual de Meio Ambiente (Sisema) de Minas Gerais, e técnicos federais, do ICMBio. Não houve acordo. O depoimento de um técnico do ICMBio sintetiza as divergências que surgiram e aponta para a tentativa de compatibilização entre os interesses econômicos e ambientais:

O [governo do] estado apresentou, já à época, propostas de desenho da Unidade de Conservação diferentes daquela que tinha sido a proposta inicial para a criação da Unidade [feita pelo ICMBio]. E, nessa discussão, houve um debate no qual o grupo técnico do ICMBio colocou, com relaçáo às alterações propostas pelo estado, a existência de impactos de incompatibilidade da conservaçáo com relação à proposta técnica original. Significaria mais ou menos o seguinte: você tem um desenho que foi proposto e levou em consideração os vários alvos de conservação existentes na área e alguns de especial relevância e interesse. [...] Antes, tinha se feito [no ICMBio] uma proposta com o objetivo de preservação do ecótono [zona de transiçāo entre biomas]. Aí, a proposta de conservação do estado retirava, excluía, partes daquilo que havia sido proposto pelo Instituto Chico Mendes inicialmente. E os técnicos do Instituto consideraram que essas exclusôes provocariam perdas significativas no caso da criação de uma Unidade de Conservação federal. E aí, particularmente, as alteraçóes propostas excluíam partes da área que eram de interesse de mineração, envolvendo diferentes empresas. E essas diferentes empresas, o que se alegou, é que estariam em processo de licenciamento ou já licenciadas para atuar na regiáo. Houve modificaçóes que foram consideradas [pelo ICMBio] parcialmente ou totalmente justificáveis, mas várias outras propostas de exclusão foram consideradas sem justificativa do ponto de vista da conservação - com justificativa econômica, mas que provocariam impacto significativo sobre a proposta de conservação (Entrevista 9, 22 de maio de 2015).

Dado o que, na fala dos entrevistados, seria um impasse "técnico" entre a proposta de conservação, prevista no projeto de criação da Unidade de Conservação do Instituto Chico Mendes, e a de compatibilização dos interesses minerários, defendidos pela equipe da Secretaria de Meio Ambiente de Minas Gerais, o entâo secretário de Meio Ambiente de Minas Gerais, Adriano Magalháes, e o então presidente do ICMBio, Rômulo Melo, se reuniram para buscar uma solução. Decidiram, então, excluir a área que seria destinada à cava da Mina Apolo da área do parque, no que ficou conhecido como "acordo Rômulo-Adriano". Na fala dos técnicos do ICMBio, era forte o argumento de que o órgáo achava imprescindível o apoio do governo do estado para a implantação do parque - e que, por isso, a conversa fora necessária.

No entanto, quando foi dada publicidade à proposta do GT1, tanto o Movimento pela Preservaçáo da Serra do Gandarela quanto a Vale se mostraram insatisfeitos. Além disso, outros grupos empresariais de menor porte, com pretensóes de atuar no território e cujos licenciamentos ambientais tramitavam no Sistema Estadual de Meio Ambiente, também se manifestaram como contrários ao acordo Rômulo-Adriano. Diante do novo impasse, o governo do estado propôs a criação de um segundo grupo de trabalho, o GT2, envolvendo não só os técnicos do 
ICMBio e da Semad, mas também ambientalistas (inclusive de fora do Movimento) e representantes das prefeituras dos municípios envolvidos, das empresas com interesse de atuar na área e das pastas de planejamento e desenvolvimento econômico do governo estadual. ${ }^{26} \mathrm{O}$ GT2 se prolongou por quatro meses, de novembro de 2011 a fevereiro de 2012, com doze reunióes marcadas por novos impasses.

Um deles dizia respeito à construção de uma dimensão pública dos encontros. O Movimento temia que o GT se convertesse em um instrumento de cooptação e legitimação, quando decisóes que contrariassem seus interesses fossem anunciadas como se tivessem tido a anuência do grupo. Para evitar a cooptação, antes que as discussôes sobre os limites do parque nacional de fato avançassem no GT2, as primeiras reunióes foram de deliberação sobre questôes procedimentais: gravar ou não os encontros, produção de atas. A posição do Movimento, que ameaçou deixar o GT se as gravaçóes não fossem feitas, acabou prevalecendo.

A metadeliberação, de alguma forma, ajudou a balizar o conflito aceitável. Essas condiçóes procedimentais de fomento à publicidade dos encontros criaram constrangimentos que ajudaram a restringir posturas coercitivas e posicionamentos que defendiam interesses puramente privados nas reunióes, ainda que não os tenham eliminado. A desconfiança quanto à forma de açáo dos atores é um claro indicativo da desconfiança mais ampla que atravessava o conflito. A publicidade foi reivindicada como forma de transformar o conflito em uma negociação mais justa e aceitável.

Inicialmente, o GT foi marcado pelos seguintes posicionamentos: 1) o Movimento pela preservação da Serra do Gandarela era irredutível quanto à manutençáo do projeto inicial do parque; b) a Vale era persistente quanto ao tamanho da área destinada à implementação da Mina Apolo e ainda apontou suas pretensões minerárias numa área ao sul, para futuras ampliaçôes; c) as administrações municipais apoiavam a proposta minerária; d) representantes do ICMBio e Semad buscavam um meio termo entre as propostas.

A tensão e o nível de divergência nos encontros eram tamanhos que o prefeito de Santa Bárbara e o representante da Associação Mineira de Defesa do Meio Ambiente (AMDA) abandonaram os debates. ${ }^{27}$
Um funcionário do ICMBio, que esteve presente nas reunióes, comenta sobre a dimensão agonística que assumiram:

Foi difícil. Alguns grupos foram intransigentes. Porque quando você abre um grupo de trabalho é exatamente para ouvir as demandas e, em cima dessas demandas, a gente conseguir trabalhar numa proposta. Então, para fazer uma proposta de consenso ou que atenda minimamente aos dois grupos, os dois grupos acabam tendo que ceder um pouco, entendeu? Mas muitas vezes, as pessoas não estavam querendo ceder. Existia essa tensão nesses momentos em que os interessados não têm interesse em ceder para uma conciliação no processo de negociaçáo. [...] Principalmente porque envolve o interesse econômico, né? Por exemplo, numa área que você envolve a extração mineral, quanto menos área estiver dentro do parque, maior a área fora do parque, maior vai ser a retirada de minério e o lucro das empresas... A discussão é com viés econômico - principalmente no caso das mineradoras (Entrevista 24, 4 de novembro de 2015).

No entanto, após uma série de apresentaçóes do ICMBio, da Vale e das demais empresas sobre as propostas em jogo, o Movimento pela Preservação Serra do Gandarela e as pequenas mineradoras começaram a ceder em suas posiçóes. O Movimento concordou em abrir mão de algumas áreas da Unidade de Conservação para a atuação de empreendimentos de pequeno porte previstos para o território. Os representantes destas empresas também abriram mão de algumas áreas previstas inicialmente para seus empreendimentos em favor do parque. ${ }^{28}$ Por outro lado, a Vale insistia em manter suas pretensóes minerárias na regiāo e a proposta em que apontava áreas em que pretendia atuar no futuro.

Entrevistas com os membros do Movimento revelam que a decisão pela abertura se deu a partir de duas questóes: 1) o entendimento de que ceder, naquele momento, projetaria, entre os interlocutores, a ideia de que o grupo não era "radical"; 2) e a avaliação de que a discussão pública e administrativa sobre a implementação do parque náo acabaria ali, 
caso fossem sugeridos encaminhamentos a partir das deliberações do GT2. Os resultados das discussōes do grupo de trabalho - que, ao fim, manteve a área proposta para a mineraçáo da Vale, mas retirando a barragem de rejeitos do projeto - serviram de base para o desenho do parque nacional, apresentado em consultas públicas realizadas pelo ICMBio.

\section{O impasse: consultas públicas e a proposta da RDS}

Seis consultas públicas sobre o Parque Nacional da Serra do Gandarela foram realizadas em 2011, cada uma em um município - Caeté, Santa Bárbara, Raposos, Rio Acima, Ouro Preto e Belo Horizonte -, a partir de uma determinaçáo do Ministério Público Federal, que pediu celeridade no processo de criação da Unidade de Conservação. De modo geral, elas tiveram formato semelhante ao das audiências: o propositor (ICMBio) tinha um tempo para expor o projeto e, depois, eram abertas falas de até cinco minutos cada para os interessados em se manifestar. As consultas aconteceram no turno da noite, durante a semana, com exceção da última, realizada em Belo Horizonte, que teve início na tarde de um sábado. Assim como as audiências, elas foram marcadas por fortes embates verbais entre ambientalistas e defensores do projeto da mina. Um analista do ICMBio que esteve diretamente envolvido com os encontros avalia que eles foram importantes para publicizar as informaçóes em análise e esclarecê-las para a populaçáo afetada, buscando desfazer distorçôes criadas pelas fake news que circulavam publicamente: por exemplo, que animais selvagens, como onças, seriam soltas em áreas próximas às casas, caso a Unidade de Conservação fosse criada.

De alguma forma, as consultas públicas buscavam retificar informaçóes sobre o processo de implementação do parque, então já em fase avançada. No entanto, um novo conflito aflorou nesse contexto. A proposta inicial do Movimento para a UC havia sido ampliada depois que o ICMBio constatara, em suas pesquisas iniciais, que outras áreas de relevância na região deveriam ser protegidas. Parte dessas áreas, porém, era de uso comum das comunidades, em atividades agrícolas e extrativistas de pequeno porte, como criação de abelhas, retirada de musgo, manejo de candeia e pastoreio de gado. A iminência da perda das terras criou resistência entre os moradores - inclusive aqueles que, anteriormente, haviam assinado a petiçáo pela criação do parque. Uma liderança comunitária da regiáo de Conceição do Rio Acima, em Santa Bárbara, dá sua versão para o que aconteceu:

A gente foi se mobilizando. Através da Associação, através do Sindicato. A gente chamou o ICMBio para ter uma discussáo com a comunidade, né? Aí tiveram vários debates, enchemos Conceição de Rio Acima de gente. Porque, na verdade, eles estavam colocando um mapa em que as divisas estavam entrando nas propriedades rurais aqui de Santa Bárbara. Na época a gente não concordou, né? Não é que é ser contra o parque. A gente defende a criaçáo do parque e que ele seja criado ao longo do Gandarela. Só que eles estavam jogando Conceiçáo do Rio Acima dentro do parque. [...] A gente brigou, questionou muito com o ICMBio nas reunióes para poder avançar (Entrevista 23, 14 de setembro de 2015).

O depoimento reforça algo que se expressa em uma frase repetida várias vezes nas conversas com moradores da regiáo: "O melhor, mesmo, é se ficasse como era: sem parque, sem mina, sem reserva". É interessante pensar que essa possibilidade não pode sequer ser aventada, diante do debate mais amplo, embora ela exista em contextos isolados. Parque e reserva, nas palavras de alguns dos moradores, acabam se tornando um mal menor:

O parque, se eu te disser que é $100 \%$ de bom, não é. Mas a gente, muitas vezes, concorda, apoiou, para evitar uma força maior, que é da Vale, porque se tiver o parque ela vai respeitar. $\mathrm{E}$ se não tiver, ela não vai respeitar (Entrevista 18, 29 de agosto de 2015).

O ICMBio contesta que o mapa do Parque Nacional da Serra do Gandarela estivesse entrando nas comunidades rurais, mas, como a UC de fato avançava sobre áreas de uso comum, fez uma série de reuniôes com as comunidades para discutir soluçóes. 
De certo modo, as discussões nas duas arenas - reunióes e consultas públicas - passaram a se retroalimentar, fazendo surgir uma nova proposta: a criação de uma Reserva de Desenvolvimento Sustentável (RDS) na região leste da serra, em substituição a parte da área que seria destinada ao parque. A RDS é um tipo de unidade de conservação menos restritiva que o parque, que só permite atividades de turismo e pesquisa científica; em princípio, ela possibilitaria compatibilizar conservação e parte das atividades econômicas dos moradores da área. Temos, nesse contexto, o surgimento de uma alternativa mediadora a partir do choque de visões antagônicas - um evidente processo deliberativo, novamente espraiado no tempo e no espaço.

Além das reunióes do ICMBio com as comunidades e do mapeamento das áreas de uso comum, também feito em parceria pelo órgão e os moradores, uma outra atividade desenvolvida a partir das articulaçóes do Movimento pela Gandarela contribuiu para fomentar o debate sobre o território. Em um período próximo das reunióes do ICMBio, em 2011, o Instituto Pró-Città, organização parceira do Movimento, iniciou um projeto para mapear as formas de uso das áreas comuns da serra, detalhando como as atividades extrativistas e agrossilvopastoris são desenvolvidas e propondo melhorias nas práticas. A pesquisa, também marcada por uma série de encontros com as comunidades, acabaria por alimentar as discussōes com o ICMBio e as consultas públicas. O relatório final aponta o clima desconfiança entre os moradores no momento da chegada da equipe do mapeamento, "tanto em função do projeto de criação do Parna Gandarela, quanto pela possibilidade de viabilização do projeto da mina Apolo" (Pró-Città, 2012, p. 10).

De todo modo, é importante frisar o quanto esses três momentos, articulados - Consultas Públicas, estudos do Parque Nacional da Serra do Gandarela e estudos do Pró-Città - acabaram criando um microssistema deliberativo de compreensão da realidade local e de construção de alternativas. E é fundamental reforçar como esses desdobramentos aconteceram, em boa parte, a partir do conflito, da resistência dos moradores da região à forma como o processo vinha sendo conduzido. O depoimento de uma moradora de André do Mato Dentro, integrante do Movimento, complementa a explicação dessa fase da Questão Gandarela:

A ideia da RDS surgiu com essas reunióes [do ICMBio] com as comunidades, que não era a consulta oficial, ainda, com relação ao parque, foi sendo apresentado esse conflito de uso da área versus unidade de proteção integral. Aí, ao apresentar as unidades de proteção integral e as unidades de uso sustentável, nesse período, estava rolando a pesquisa do [Instituto] Pró-Cittá, e a gente até redirecionou - já era mapear as atividades que existiam: onde é que era coletado o musgo, onde é que são os apiários... aí, dentro. Dentro desse momento muito conflituoso das pessoas contra o parque, surgiu como uma mediadora, como uma conciliação, a ideia da reserva (Entrevista 2, 14 de março de 2015).

Interessante observar, dessa forma, como um projeto conflituoso pode abrir portas para novas perspectivas de vida para um determinado grupo, no caso, lançando novos olhares para um território e seus modos de uso. Os deslocamentos se mostram base importante para a construção ou projeção de novos mundos. Esse processo de discussão com a comunidade, em que as vontades e propostas foram construídas durante, e não definidas a priori, remete-nos à formulaçáo de Benhabib, que destaca a incoerência de se esperar que os indivíduos tenham clareza sobre suas escolhas e preferências antes de passarem por um processo bem-sucedido de deliberação: "A formação de preferências coerentes náo pode proceder a deliberação; ela só pode sucedê-la” (Benhabib, 2009 [1996], p. 115).

O mapa abaixo (Figura 1) mostra como ficaria o território a partir da incorporação da proposta da RDS pelo ICMBio, reduzindo a área prevista para o parque mas levando em consideração as áreas de uso das comunidades como territórios a serem conservados de modo específico.

É preciso considerar, no entanto, que a elaboração da proposta da RDS - que deveria partir das comunidades, como vimos - foi marcada por desconfianças e muitas tensões. Na região de André do Mato Dentro e Cruz dos Peixotos, responsável por desenvolver cerca de 


\section{FIGURA 1 - PROPOSTA DO PARQUE E DA RDS, SEM A MINA}

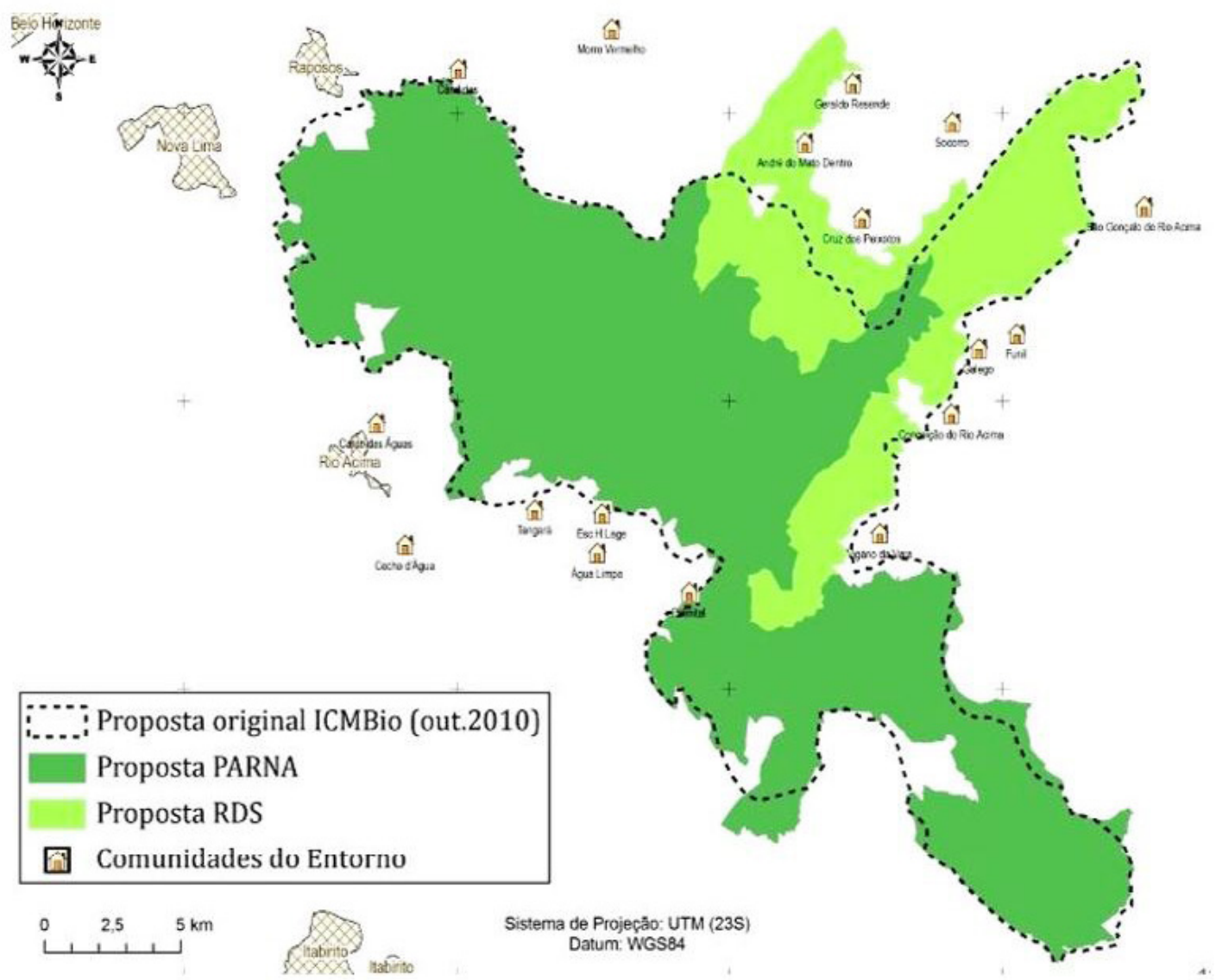

Fonte: Movimento pela Preservação da Serra do Gandarela

metade da proposta, o processo de elaboração fluiu mais rapidamente graças à presença de representantes do Movimento. Já nas comunidades a leste, no eixo de Conceição do Rio Acima, houve demora, em parte devido à disseminação de informaçóes falsas, como já mencionamos, em parte devido à preferência de alguns moradores pela efetivação da atividade mineradora.

A partir de uma nova intervenção do Ministério Público, determinando que as audiências fossem finalizadas e a avaliação concluída, o ICMBio finalizou a proposta do Parna e a enviou, em 2012, ao Ministério do Meio Ambiente, responsável pelo encaminhamento político da questão e por negociar a demanda com a Casa Civil e a presidência da República. Caberia à presidência decretar ou não a criação do parque, ou seja, garantir a efetividade da implementação dos resultados do processo deliberativo que se constituíra, garantindo a consequencialidade da deliberação defendida por teóricos (ex. Thompson, 2008; Dryzek, 2017).

\section{O balde de água fria: legitimidade e o decreto presidencial}

Um desafio permanente do Movimento era questionar o discurso segundo o qual as mineradoras não podem ser contrariadas e questionadas devido ao seu poderio. É o que aponta uma ambientalista:

Eu já ouvi muito isso: "ah, a Vale é grande e eles vão conseguir [operar]". Isso está incrustado de tal modo no povo mineiro, de uma tal forma... E está incrustado nos grandes, até nos próprios 
políticos. Muitas vezes eu acho que muitos têm medo. Não é porque eles estão recebendo dinheiro por fora. É porque eles não acreditam que seja possível (Entrevista 3, 23 de março de 2015).

Como a entrevistada reforça, o confronto está muito além das dimensóes materiais, e dos valores que os sujeitos têm em relação ao ambiente, perpassando o questionamento de relaçóes de subordinação que se convencionou naturalizar, diante de atores que detêm grande poderio econômico. Ainda que essas relaçôes não tenham se alterado, porém, entendemos que é preciso considerar, ao menos, o fato de que elas foram colocadas publicamente e foram submetidas ao escrutínio e tornadas perceptíveis.

A criação do parque nacional seria decretada em outubro de 2014 - sem a RDS, ${ }^{29}$ com uma área menor que a prevista e avançando sobre parte dos territórios de uso comum das comunidades. A partir do momento em que o ICMBio finalizou as propostas e as encaminhou para discussáo interna dentro do executivo federal, os canais de interação entre Estado e sociedade civil ficaram mais restritos, com o Movimento deixando de ter interlocução direta com os responsáveis pelo encaminhamento dos projetos. ${ }^{30}$ Os defensores do parque, no entanto, mantiveram contato com os órgáos do governo federal e participaram de negociaçóes diretas, como confirma a fala de um ex-prefeito da regiấo:

Eu já tinha deixado a prefeitura, isso foi no ano de 2014, eu ajudei lá [no Ministério do Meio Ambiente], fiz várias reuniōes lá. Aí acabou saindo. O Ministério do Meio Ambiente acabou publicando a criação do parque tirando a área da Vale. Só que na hora que fez isso já foi num momento em que aqui não licenciou [a mina] e agora, com a turbulência econômica, acabou com tudo, na minha opinião ${ }^{31}$ (Entrevista 12, 22 de julho de 2015).

Em entrevista, um funcionário indicado pela Vale para colaborar com esta pesquisa afirmou que, nos encontros em Brasília, a empresa somente forneceu ao governo federal documentos, como mapas e pesquisas sobre o ecossistema da regiáo, de modo a contribuir para a decisão final, e que seus representantes compareceram aos encontros a partir da demanda dos ministérios envolvidos - além do Meio Ambiente, o Ministério das Minas e Energia também participou das conversas finais, uma vez que boa parte da área da Serra do Gandarela está dividida em licenças de lavra (Entrevista 25, 12 de fevereiro de 2016).

$\mathrm{O}$ fato de a mineração ter ficado, indiretamente, possibilitada, aliado à náo criação da reserva, foi motivo de desapontamento entre os moradores das comunidades. A decisão presidencial foi vista como uma negação de parte substancial do processo e, em alguma medida, como algo carente de legitimidade, já que não se respeitou o posicionamento de uma parte significativa dos concernidos que se colocaram publicamente sobre a questáo. $\mathrm{O}$ poder da dimensão econômica, em detrimento da valorização de processos que passaram pelo escrutínio público, é explicitado no tom de descrença do depoimento de um morador do André do Mato Dentro:

Eu sempre falei: "no final, quem ganha é sempre quem tem dinheiro". Eu sempre falei: tenho certeza que, no final, eles vão acabar fazendo um acordo. Aí, agora, o que vai acontecer? A Vale vai prejudicar a gente lá em cima e o parque aqui embaixo. E a gente vai ficar sem meio (Entrevista 20, 29 de agosto de 2015).

A questão, ao nosso ver, é como a legitimidade (ou não) da decisão se relaciona ao debate público sobre a Questão Gandarela. Dryzek (2000) afirma que o impacto da pressão dos grupos da sociedade civil sobre o Estado sempre está sujeito aos imperativos que este segue. A questão é que, numa democracia, tais imperativos não são necessariamente estanques: "Ao menos quando eles [grupos] atuam sobre funçôes essenciais do Estado, grupos oposicionais [da sociedade civil] só podem ser incluídos pelo Estado de forma benigna quando os interesses definidores do grupo são diretamente relacionados a um imperativo do Estado" (Dryzek, 2000, p. 96). ${ }^{32} \mathrm{O}$ ponto é que, apesar de a questão ambiental ser um dos imperativos dos Estados contemporâneos, como posto pelo próprio autor, no caso do Brasil, ele está longe de ser considerado 
imperativo prioritário - ao contrário do que acontece com a questáo fiscal e a agenda exportadora, por exemplo, que se relacionam diretamente à pauta de expansão minerária dos anos 2000 e 2010 . Há de se considerar, também, como lembra o autor, o peso das áreas responsáveis por esses diferentes imperativos dentro do Estado e a competição entre elas.

Ao nosso ver, no entanto, isso não justifica a forma como a decisão sobre a criação do Parque Nacional da Serra do Gandarela foi tomada, e projeta questionamentos sobre a legitimidade das decisóes, principalmente na medida em que estas negam um longo processo de debate envolvendo vários setores da sociedade. É como se muito do conflito e da deliberação precedentes não tivesse sido levado em conta, já que parte dos atores envolvidos acionou um atalho em direção ao governo, por fora da esfera pública, no momento da tomada de decisão. O poder comunicativo foi superado pelo estratégico? Talvez seja o caso de pensar como o poder discursivo da burocracia estatal e da sociedade civil foi mais frágil que o poder econômico de grupos externos ao Estado no acesso ao centro de tomada de decisão representado pela presidência.

A necessidade de interconexão entre diferentes arenas e a forma como isso afeta a tomada de decisão sáo discutidos, entre outros autores, por Hendriks (2006a, 2006b), que questiona a proposta de separação do campo em teorias micro e macro deliberativas. ${ }^{33}$ O interesse está em como essa deliberação, aparentemente desestruturada, aberta e informal capitaneada pela sociedade civil é capaz de "formatar" a opinião pública e, consequentemente, as instituiçóes políticas. Assim como Dryzek (2000) e Habermas (1996), Hendriks contesta a suposta incapacidade da deliberação de lidar com formas estratégicas de ação: "[a]ltamente imprevisível, a deliberação discursiva não exclui, necessariamente, formas mais estratégicas de ação, como protestos, boicotes e ativismo radical (Hendriks, 2006b, p. 494)". ${ }^{34}$

No entanto, assim como Habermas, ela também aborda a necessidade de prestar atenção às forças repressivas e excludentes que existem na esfera pública, devido aos efeitos da distribuição desigual de poder, da violência estrutural e das distorçóes de comunicação. ${ }^{35}$ Sem detalhar essa questão, Habermas (1996) chega a propor o estabelecimento de salvaguardas institucionais que tensionem essas forças - como acreditamos ser o papel do Ministério Público no caso específico da Questão Gandarela. Também fala da necessidade da própria sociedade civil de contar com movimentos sociais capazes de evitar esse tipo de distorção - atuando, ao mesmo tempo, nas bases populares e no centro das decisóes políticas.

É evidente que a separação entre os dois níveis (micro e macro) nem sempre é táo precisa. No nosso caso, por exemplo, o Movimento pela Preservação da Serra do Gandarela atua tanto por meio de mobilizações no nível macro, ocupando espaços públicos, em mídias sociais, ou se articulando com outros movimentos ambientalistas, quanto nas arenas institucionalizadas pelo Estado para debater a questão, como audiências e consultas públicas, grupos de trabalho e conselhos municipais de meio ambiente - as chamadas esferas híbridas. E ainda assim, ele não dá conta de constranger todas as distorções presentes no processo, o que reforça a preocupação de Boswell (2014) quanto aos riscos da dominaçáo dos espaços de debate pelos atores com mais recursos.

O caminho proposto por Hendriks é pensar como se dá a costura entre esses diferentes níveis a partir da lógica sistêmica apontada por Mansbridge (1999). "Conceber a democracia deliberativa inteiramente como uma iniciativa micro ou macro não é somente irrealista como potencialmente excludente. Na prática, todos os fóruns microdeliberativos são rodeados e impactados por seus macrocontextos discursivos" (Hendriks, 2006a, p. 502). Isso fica evidente quando analisamos a forma como as múltiplas arenas da Questão Gandarela se retroalimentam e, em determinados momentos, também dialogam com os modos de vida das comunidades no entorno; ou tem pontos que atravessam outros debates, como o caso dos desastres da Samarco/Vale-BHP Billiton, em Mariana, em 2015, e da Vale, em Brumadinho, em 2019, nos quais alguns integrantes do Movimento pela Preservação do Gandarela se engajariam. 


\section{Discussáo}

Consideramos, assim, que a Questão Gandarela é composta por um emaranhado de momentos conflitivos, institucionalizados ou náo, que ao nosso ver contribuíram para a emergência do debate público em torno da questáo. Foram significativos, ao nosso ver: 1) as reuniôes de apresentação do projeto de mineração da Vale às comunidades locais, a partir de 2007 ; 2) as audiências públicas do processo de licenciamento do projeto Apolo, em 2010;3) os grupos de trabalho criados pelo governo de Minas Gerais para buscar conciliar os projetos minerador e da Unidade de Conservação, entre 2010 e 2011; 4) as consultas às comunidades para a implementação do Parque Parque Nacional da Serra do Gandarela, em 2011 ; 5) as consultas públicas para a implementação do parque, em 2011; e 6) as ações de mobilização (passeatas, manifestaçóes na serra, ativismo em mídias sociais, reunióes com as comunidades) do Movimento pela Preservação da Serra do Gandarela, que atravessam as outras cinco esferas e se estendem temporalmente de 2009 até o presente.

A análise do caso revela alguns pontos interessantes para a discussão sobre deliberação. Observa-se: 1) a existência de um grande sistema discursivo cujos protagonistas são movimentos sociais, empresas, políticos municipais, moradores das comunidades, burocratas de instituiçóes ambientais, promotores e procuradores; 2) que esse sistema tem como principais arenas reunióes com comunidades, conselhos municipais de meio ambiente, consultas e audiências públicas, grupos de trabalho e os media; 3) que a perenidade desse sistema está relacionada a) à agência do Movimento pela Preservação da Serra do Gandarela; b) à agência e porosidade de parte do Ministério Público Federal e do Ministério Público Estadual à causa; c) à agência e porosidade do aparato burocrático federal (ICMBio) à causa; d) à existência das demais arenas; e e) a embates disruptivos que chamam atenção para a causa, convocando o posicionamento de agentes do Estado e dos cidadãos concernidos e oferecendo uma diversidade de pontos de vista, ainda que marcado por graves situações de desrespeito, violência, constrangimentos, assimetrias de poder e disseminação de informaçôes inverídicas; e por fim 5) que é possível identificar transformaçóes no entendimento dos atores a respeito dos objetos em questão (como a percepção da existência da serra por parte dos moradores da região, a construção da proposta da RDS etc.).

É preciso reforçar que a agência do movimento social foi central para que os fluxos discursivos envolvidos nesse processo não cessassem. Muitas vezes, o debate fomentado por ele promoveu reflexividades que abriram espaço para o conflito. Em outras, o confronto foi a chave que (re)abriu as portas entre as diferentes arenas e permitiu que o processo fosse retomado ou construído. O trabalho, assim, reforça o papel primordial que a sociedade civil desempenha na construção e na manutenção da esfera pública enquanto ente mediador entre o Estado e cidadãos ordinários, com sua capacidade de organizar demandas sociais, enfeixá-las e direcioná-las discursivamente tanto para esse Estado quanto para outros cidadãos, conforme defendido por Habermas (1996) e Dryzek (2000). Isso se deu em meio a relaçóes raramente amistosas, marcadas por tensóes, discrepâncias econômicas que interferem no acolhimento de demandas e diferenças de valores entre demandantes e representantes formais do Estado. Some-se, ainda, o fato de o processo envolver relaçóes marcadas por acessos assimétricos aos centros de tomada de decisão, pela existência de instituiçóes com desenhos participativos ainda relativamente precários, pela coerção de adversários poderosos e pela disseminaçáo do medo como mecanismo de barrar o questionamento.

Uma questão fundamental a ser considerada sempre é se há "compromisso com a maximização de acesso livre, igual e autêntico ao debate, estendido a indivíduos, interesses e grupos tradicionalmente excluídos da tomada de decisóes" (Dryzek, 2000, p. 86). Houve deliberação? Acreditamos que, ainda que essa não tenha sido a proposta de todas as partes envolvidas, sim. Houve inclusão das perspectivas (e mesmo participação presencial) dos principais atores diretamente afetados, ao mesmo tempo em que cidadãos interessados foram mobilizados pela questão. Houve processos de justificação mútua (reason giving) sobre as posiçóes em jogo (nas audiências públicas, nas consultas públicas, nas reunióes sobre o parque e sobre a comunidade, nos grupos de trabalho), com escutas razoavelmente engajadas dos interlocutores em 
boa parte do processo, possibilitando o surgimento de contra-argumentos (Niemeyer e Jennstal, 2018; Bächtiger e Parkinson, 2019). E houve uma efetividade relativa das discussões, a partir do momento em que resultam em medidas administrativas (suspensão temporária do licenciamento da mina, avaliação do projeto do parque e da RDS, criação parcial do parque), mas também em mudanças na forma como os grupos avaliam os conjuntos de questôes discutidas. Dryzek $(2017,2010)$ aponta essas transformaçôes como uma dimensão da efetividade deliberativa a ser considerada também, para além da forma como governos procedem a partir da deliberaçáo. Isso não significa que devamos nos esquecer dos impactos das outras formas de açáo que levaram o Executivo a fazer a concessōes ao projeto minerador, e nem tampouco desconsiderar que isso mereça ser mais bem avaliado por pesquisas da corrente.

De todo modo, pensando nas premissas dessa pesquisa, é preciso lembrar que o que faz um sistema deliberativo ser de fato deliberativo não é a existência de deliberação em todas as fases de um processo. Em um sistema deliberativo, o que podemos discutir é se os critérios deliberativos poderiam ser incrementados nos momentos em que se fazem menos presentes. E sobre como o aperfeiçoamento de instituições, a redução de desigualdades sociais e econômicas e o incremento de virtudes cívicas dos cidadãos (Böker, 2016; Dryzek, 2017) poderiam levar à existência de sistemas deliberativos também eles mais virtuosos e efetivos, que resultem em decisōes implementadas de forma legitimada.

Retomando Habermas, talvez seja possível pensar o Movimento pela Preservaçáo da Serra do Gandarela como um grande questionamento de pretensóes de verdade e de correção: da ideia que a mineração forja a identidade dos mineiros; da ideia que a mineração é a única opção para o desenvolvimento local; de que a mineraçẫo seja a melhor forma de uso/ocupação de uma serra. Ao dizer não a essas coisas, o Movimento provoca um processo de reflexividade sobre os nossos mundos objetivo, social e subjetivo: dos moradores da regiáo sobre a serra e também do próprio Estado, que passa a considerá-la materialmente não só como um amontoado de minério de ferro que pode render tributos, ainda que essa dimensão náo tenha sido apagada e permaneça forte. Num processo em que o próprio Movimento revê suas posiçóes e passa a considerar outras possibilidades a partir dos posicionamentos dos moradores, a grande questão é essa: com o não, o conflito provoca a reflexividade. Isso não pode ser minimizado.

É claro que a racionalidade estratégica perpassa todo o processo. E ela não deve ter a sua importância apagada nem negligenciada, o que seria até uma ingenuidade. Mas a postura do Movimento de negar o projeto minerador, ainda que com algumas flexibilizaçôes ao longo do percurso, possibilita que elementos dessa reflexividade comunicativa se irradiem publicamente. Ao mesmo tempo, o inverso também é notado: a reflexividade pode levar ao conflito, na medida em que expõe situaçóes de injustiça que podem gerar resistências.

\section{Consideraçóes finais}

Nosso trabalho se propôs a reconstituir o processo político sobre o conflito ambiental envolvendo o futuro da Serra do Gandarela, a partir de uma abordagem metodológica interpretativa, balizada por elementos da abordagem sistêmica da deliberação. Pretendíamos, com isso, reforçar a indissociabilidade entre conflito e deliberação. Após breve apresentação de nossas bases teóricas e metodológicas, reconstituímos o conflito ambiental com base nos momentos deliberativos que estruturam a questão.

Em resumo, como contribuiçáa, acreditamos que o trabalho traz sete questóes fundamentais: 1) reforça a indissociabilidade entre conflito e deliberação; 2) aponta para o papel-chave da atuação da sociedade civil no fomento do debate público, na criação e projeção de modos alternativos de ver o mundo, na atuação do Estado, e na construçáo de políticas públicas; 3) reforça o potencial revelador de metodologias interpretativas nos estudos de ciência política e deliberação; 4) aponta para a urgência e o potencial de se ampliar as análises sobre processos deliberativos para além de fóruns fechados (como conferências, conselhos e orçamentos participativos), a fim de se compreender a conexão desses espaços com práticas políticas extrainstitucionais, e das percepçôes e práticas dos cidadáos sobre política; 5) aponta para o papel 
desempenhado por operadores do direito (Ministério Público) na reverberação pública de questóes e no andamento de processos na esfera pública; 6) reforça a necessidade de se estudar melhor as interferências do lobby e outras formas de intervenção do poder econômico em processos de discussão pública; e, por fim, 7) aponta a necessidade de aprofundar a compreensão dos processos políticos envolvidos na expansão da atividade mineradora que ocorreu no Brasil nos anos 2000 e 2010, ação já iniciada por campos de pesquisa como a geografia e a antropologia, mas que merece ter contribuiçóes mais robustas da ciência política e da sociologia, como os desastres ambientais de Mariana e Brumadinho evidenciam.

\section{AGRADECIMENTOS}

Este trabalho foi escrito com o suporte de bolsas de mestrado e doutorado da Coordenação de Aperfeiçoamento de Pessoal de Nível Superior (CAPES). Agradeço aos pareceristas anônimos pelos comentários e sugestóes, e a Ricardo Fabrino Mendonça, Gabriella Hauber e Rafael Sanches pelas leituras críticas de versóes preliminares.

\section{Notas}

1 Diversos autores trabalharam para apontar a dimensão conflitiva da deliberação. Defendendo o embate com o outro e o choque de perspectivas como base da corrente, Mendonça (2011, p. 209), por exemplo, aponta que "a compreensão inadequada dos requisitos de mutualidade" e "a visão de que deliberaçóes aspiram consensos substantivos" levaram à leitura consensualista equivocada da teoria. Mesmo em Gutmann e Thompson (2004), a construção do consenso estaria fundada na divergência, numa economia do desacordo moral que permita lidar com discordâncias profundas sobre questôes políticas ideia também observada por Dryzek (2005), em outra chave. Além disso, autores como Mansbridge et al. (2010) e Curato et al. (2019) advogam pela leitura de relaçôes de poder, de apelos emocionais e da expressão de sentimentos fortes nos processos deliberativos. Este trabalho, desta forma, reforça a importância do conflito levantada por outros autores.

2 Entre as iniciativas nesse sentido, destacam-se os trabalhos de Stevenson e Dryzek (2014), sobre a deliberação global a respeito de mudanças climáticas, pouco debatido pelo campo; o de Silva e Ribeiro (2016), sobre os conectores de subsistemas deliberativos de conselhos de políticas públicas em Belo Horizonte (MG); e, no campo da comunicação, Miola (2012) sobre o debate público em torno da criação da EBC, no Brasil.

3 Literatura que também corrobora a relação entre conflito e deliberação e refuta a leitura consensualista levantada por críticos da corrente.

4 Além disso, os autores defendem a comparação entre análises densas de sistemas deliberativos, o que não conseguimos fazer neste trabalho.

5 Resumidamente, o modelo projeta a porosidade e a alimentação discursiva de espaços políticos formais de deliberaçáo por demandas oriundas de debates e choques de ideias que ocorram na esfera pública informal (Habermas, 1996).

6 Considerando-se que essa escuta engajada não se dá necessariamente ao mesmo tempo por todos os atores, o que poderia inclusive ser opressor, apontam os autores. E que esse provimento de razóes acontece nas açôes de movimentos, nas trocas de argumentos em arenas formais, informais etc.

7 De forma sucinta, o ponto de partida de Goodin é excessivamente institucional, focado no parlamento.

8 O uso de entrevistas para a reconstruçáo de processos sistêmicos na deliberação vem sendo adotado por outros pesquisadores desta corrente (Hendriks, 2016; Boswell, Hendriks e Ercan, 2016; Mendonça e Ercan, 2015).

9 O projeto Apolo previa a implementação de uma mina orçada, à época, em R \$ 4,4 bilhôes, e com capacidade de extração de 24 milhôes de toneladas de minério de ferro/ano, o que a situaria entre as maiores de Minas Gerais.

10 Para outras descrições e análises sobre a Questão Gandarela, sempre com centralidade no conflito, ver Rojas (2012) e Rojas e Pereira (2015) e a tese de doutorado de Carolina Herrmann Coelho-de-Souza (2015), que foi ativista do Movimento pela Preservação da Serra do Gandarela.

11 Aqui também caberia a ideia de democracia discursiva de Dryzek (2000), composta por engajamentos dispersos e de discursos espraiados na esfera pública, com resultados capazes de afetar decisóes coletivas.

12 De perfil rural, o subdistrito de Santa Bárbara contava com pouco mais de cem moradores à época das discussões sobre o caso, a maior parte deles dedicada à agricultura familiar, em atividades como produçáo de mel (PróCittá, 2012).

13 Município da regiáo metropolitana de Belo Horizonte, também na região da Serra do Gandarela. 
14 Um sinclinal é uma estrutura geológica com dobras voltadas para cima. No caso do Gandarela, essas dobras, associadas à presença das cangas, facilitam o recolhimento de águas das chuvas.

15 Procedimento simplificado de licenciamento ambiental que existe em Minas Gerais.

16 A APA Sul é uma unidade de conservação de uso sustentável que se estende por áreas serranas ao sul de Belo Horizonte, abrangendo parte do Gandarela. Seu objetivo é preservar mananciais estratégicos. Nela, não houve desapropriaçóes de terras; somente, em tese, restrição de atividades econômicas predatórias.

17 O Ribeirão da Prata ainda contribui para o aumento da vazão e da qualidade das águas do Rio das Velhas, desaguando abaixo da captação de água de Bela Fama, responsável pelo abastecimento de cerca de $70 \%$ de Belo Horizonte e $60 \%$ de sua Região Metropolitana (RMBH).

18 É preciso ponderar os riscos de a atuação do MP ofuscar a atuação discursiva da sociedade civil; e de alteraçóes na chefia do órgão, cujo procurador-chefe é indicado pelo Executivo, interferirem na atuação dos procuradores na ponta. Além disso, a ação por meio de Termos de Ajustamento de Conduta e outras ferramentas tem sido muito questionada, por fomentar a construção de consensos e a negociação de direitos. A esse respeito, ver, por exemplo, discussōes no livro organizado por Zhouri e Valencio (2014).

19 O "direito a dizer não" é um dos focos centrais da tese de doutorado $O$ 'Espaço de Resistência' na Serra do Gandarela, de Carolina Herrmann Coelho-de-Souza, ambientalista do Movimento pela Preservaçáo da Serra do Gandarela, defendida no Programa de Pós-Graduaçáo em Arquitetura e Urbanismo da Universidade Federal de Minas Gerais em 2015.

20 Tradução nossa. Original em inglês.

21 Foram realizados encontros em Santa Bárbara, Ouro Preto, Caeté, Raposos, Belo Horizonte, Nova Lima.

22 O que foi lido por atores da sociedade civil como tentativa de intimidar os que eram contrários ao projeto.

23 Carvalho ocupou o cargo entre 1995 e 1998, e de 2007 a 2010. Também foi secretário-executivo (1999-2002) e ministro do Meio Ambiente (2002).

24 Disponível em http://www.2005-2014.agenciaminas. $\mathrm{mg}$.gov.br/noticias/aecio-anuncia-investimentos-de-r95-bi-da-vale-em-minas-2/ . Acesso em 17 de fevereiro de 2020.

25 José Carlos Carvalho discorda: ele afirma que, antes do ICMBio assumir o processo de criaçáo do parque nacional, a Secretaria de Meio Ambiente tinha a proposta de criar, na regiáo do Gandarela, um corredor ecológico composto por um mosaico de unidades de conservação.

26 No total, o GT tinha quinze membros institucionais. Além da Vale, por meio do Sindicato do setor, foram representados os grupos empresariais Mundo Mineraçáo e Mineraçáo Serras do Oeste, de ouro; Ferro Puro, de minério de ferro; Pedreira Um Valemix, de brita. Semad, ICMBio e Vale tinham direito a duas cadeiras, cada; Secretaria de Desenvolvimento (MG), Ibama, prefeituras de Santa Bárbara e Raposos, Instituto Guaicuí/Projeto Manuelzão, Macaca, Instituto Pró-Città, Associação Mineira de Defesa do Meio Ambiente AMDA e SindiExtra-MG, uma cadeira cada (Minas Gerais e Brasil, 2012).

27 O prefeito foi substituído pelo entáo secretário de Meio Ambiente do município.

28 Entre os os pontos acordados, estão, por exemplo: após pedido do Movimento pela Preservaçáo da Serra do Gandarela, o Grupo Minerita, da Ferro Puro, se dispôs a retirar o alojamento previsto para o empreendimento de uma área de Mata Atlântica, reduzindo o impacto sobre a serra; a Mundo Mineração abriu mão de uma área do seu empreendimento que seria destinada ao parque, assim como a MSOL; e a Pedreira Um abriu máo da estrada de acesso da área da serra - que, no entendimento do Movimento, poderia servir de base para o acesso à entrada no Parque.

29 Em entrevistas ao pesquisador, funcionários do ICMBio creditaram a não criação da RDS a uma visão negativa do Ministério de Meio Ambiente, à época, quanto à efetividade das reservas de desenvolvimento sustentável como instrumento de política pública ambiental. Não houve justificativa pública do governo a respeito da decisão.

30 Abers e Oliveira (2015) apontam que, a partir da saída do ambientalista Carlos Minc (2008-2010), sucessor de Marina Silva (2003-2010), e da posse da bióloga Isabela Teixeira (2010), funcionária pública de carreira, reforça-se o processo de burocratização dos funcionários do Ministério, que deixa de contar com uma presença mais forte de técnicos ligados a organizaçóes da sociedade civil.

31 Em 2019, a Vale reapresentou o pedido de licenciamento do projeto; a projeçấo da extração anual foi reduzida de 24 para 17 milhóes de toneladas de minério, com produção a seco (sem barragem de rejeitos). Novas audiências públicas eram esperadas para 2020.

32 Tradução nossa. Original em inglês.

33 O nível micro preocupa-se com o nível procedimental da corrente e com as suas condiçôes ideais de funcionamento. Já o macro "enfatiza formas discursivas informais de deliberação, que têm lugar na esfera pública. (...) Seu foco 
primário são as conversaçóes abertas e desestruturadas que se dão fora das instituições formais de tomada de decisão" (Hendriks, 2006b, p. 487. Tradução nossa).

34 Tradução nossa. Original em inglês.

35 Problemas que, na leitura de Habermas (1996), seriam corrigidos dentro da institucionalidade dos corpos legislativos.

\section{BIBLIOGRAFIA}

ABERS, Rebecca \& OLIVEIRA, Marilda de. (2015), "Nomeações políticas no Ministério do Meio Ambiente (2003-2013): interconexôes entre ONGs, partidos e governos”. Opin. Publica, vol.21, n.2, pp.336-364. DOI:10.1590/180701912015212336.

ACSELRAD, Henri. (2010), "Ambientalização das lutas sociais: o caso do movimento de justiça ambiental”. Estudos Avançados (USP. Impresso), v. 24, pp.103-120.

ALMEIDA, Débora Rezende \& CUNHA, Eleonora Schettini. (2016), "Brazilian Social Assistance Policy: an empirical test of the concept of deliberative systems". Critical Policy Studies, v. 10, pp.1-21.

BÄCHTIGER, Andre \& PARKINSON, John. (2019), Mapping and measuring deliberation: Towards a new deliberative quality. Oxford, Oxford University Press.

BÄCHTIGER, Andre; DRYZEK, John; MANSBRIDGE, Jane \& WARREN, Mark (2018), "Introduction". In: BÄCHTIGER, Andre; DRYZEK, John; MANSBRIDGE, Jane \& WARREN, Mark (orgs.), The Oxford Handbook of Deliberative Democracy. Oxford, Oxford University Press.

BENHABIB, Seyla. (2009), "Rumo a um modelo deliberativo de legitimidade democrática". In: MARQUES, Ângela Cristina Salgueiro. $A$ deliberação Pública e suas dimensóes sociais, políticas e Democráticas. Belo Horizonte, Autêntica.

BOKER, Marit. (2016), "Justification, critique and deliberative legitimacy: The limits of mini-publics". Contemporary Political Theory. 16. 10.1057/ cpt.2016.11.
BOSWELL, John \& CORBETT, Jack. (2015), "Embracing impressionism: revealing the brush strokes of interpretive research". Critical Policy Studies, 9(2), pp.216-225.

BOSWELL, John.; HENDRIKS, Carolyn \& ERCAN, Selen. (2016), "Message received? Examining transmission in deliberative systems". Critical Policy Studies. 10:3, 263-283. DOI: 10.1080/19460171.2016.1188712.

CHAMBERS, Simone. (2017), "Balancing epistemic quality and equal participation in a system approach to deliberative democracy", Social Epistemology, 31:3, pp.266-276. DOI:10.1080 /02691728.2017.1317867

COELHO-DE-SOUZA, Carolina Hermann. (2015), O "Espaço de Resistência" na Serra do Gandarela. Tese de doutorado em arquitetura e urbanismo, Escola de Arquitetura da UFMG, Belo Horizonte.

CURATO, Nicole; HAMMOND, Marit \& MIN, John. (2019), Power in Deliberative Democracy: Norms, Forums, Systems. Nova York, Palgrave.

DODGE, Jennifer. (2014), "Civil society organizations and deliberative policy making: interpreting environmental controversies in the deliberative system”, Policy Sciences, 47, pp.161-185

DRYZEK, John. (2000), Deliberative Democracy and Beyond. Oxford, Oxford University Press.

DRYZEK, John. (2010), Foundations and frontiers of deliberative governance. Oxford, Oxford University Press.

DRYZEK, John. (2017), “The Forum, the System, and the Polity: Three Varieties of Democratic Theory", Political Theory, 45, 5.

FARIA, Claudia Feres. (2017), "Sistema deliberativo, formas de conexão e inclusão política: alcance teórico e prático". Revista Brasileira de Ciências Sociais, v. 32, n. 95. DOI: 10.17666/329502/2017

FELICETTI, Andrea. (2018), Deliberative Democracy and Social Movements: Transition Initiatives in the Public Sphere. Nova York; Londres, Rowman Littlefield.

GOODIN, Robert. (2005), "Sequencing deliberative moments”. Acta Politica, 40, n.2, julho, pp. 182-196 (15). 
GUTMANN, Amy \& THOMPSON, Dennis. (2004), Why Deliberative Democracy. Princeton e Oxford, Princeton University Press.

HABERMAS, Jürgen. (1996), Between facts and norms. Boston, MIT University Press.

HABERMAS, Jürgen. (2006), "Political Communication in Media Society: Does Democracy Still Enjoy an Epistemic Dimension? The Impact of Normative Theory on Empirical Research". Communication Theory, v.16, p.4.

HABERMAS, Jürgen. (2012), Teoria do Agir Comunicativo. São Paulo, Martins Fontes.

HENDRIKS, Carolyn. (2006), "Integrated Deliberation: Reconciling civil society's dual role in deliberative democracy”. Political Studies, 54(3), pp.486-508.

HENDRIKS, Carolyn. (2006), "When the forum meets interest politics: strategic uses of public deliberation". Politics and Society, 34 (4), pp.571602.

HENDRIKS, Carolyn. (2016), "Coupling citizens and elites in deliberative systems: The role of institutional design". European Journal of Political Research, 55, pp.43-60.

KNOPS, Andrew. (2007), "Debate: Agonism as Deliberation? On Mouffe's Theory of Democracy". Journal of Political Philosophy, 15(1).

LACLAU, Ernesto \& MOUFFE, Chantal. (2015), Hegemonia e estratégia socialista: por uma politica democrática radical. São Paulo: Intermeios.

LAMOUNIER, Wanderson. (2009), Patrimônio natural da Serra do Gandarela e seu entorno: análise ambiental como subsidio para a criação de unidades de conservação no Quadrilátero Ferrifero - Minas Gerais. Dissertação. Belo Horizonte, Universidade Federal de Minas Gerais - IGC.

LANDEMORE, Hélène. (2013), Democratic reason. Princeton, Princeton University Press.

LOSEKANN, Cristiana. (2013), "Mobilização do direito como repertório de ação coletiva e crítica institucional no campo ambiental brasileiro". Dados, v. 56, pp. 311-349.

MAIA, Rousiley. (2012), Deliberation, the Media and Political Talk. Nova York: Hampton Press.

MAIA, Rousiley. (2018), "Deliberative Media”. In: BÄCHTIGER, Andre; DRYZEK, John; MANSBRIDGE, Jane; WARREN, Mark. (orgs.).
The Oxford Handbook of Deliberative Democracy. Oxford, Oxford University Press, pp.348-364.

MANSBRIDGE, Jane. (1999), "Everyday talk in the deliberative system". In: MACEDO, Stephen (ed.). Deliberative Politics: Essays on Democracy and Disagreement. Oxford, Oxford University Press, pp. 1-211.

MANSBRIDGE, Jane; BOHMAN, James; CHAMBERS, Simone; CHRISTIANO, Thomas; FUNG, Archon; PARKINSON, John; THOMPSON, Dennis \& WARREN, Mark. (2012), "A systemic approach to deliberative democracy". In: PARKINSON, John \& MANSBRIDGE, Jane (orgs.). Deliberative systems: deliberative democracy at the large scale. Cambridge, Cambridge University Press, pp.1-26.

MANSBRIDGE, Jane; BOHMAN, James; CHAMBERS, Simone; ESTLUND, David; FOLLESDAL, Andreas; FUNG, Archon; LAFONT, Cristina; MANIN, Bernard \& MARTÍ, José Luís. (2010), "The Place of Self-Interest and the Role of Power in Deliberative Democracy”. Journal of Political Philosophy, 18, pp.64-100. DOI:10.1111/j.14679760.2009.00344.x

MENDONÇA, Ricardo Fabrino \& ERCAN, Selen. (2015), "Deliberation and protest: strange bedfellows? Revealing the deliberative potential of 2013 protests in Turkey and Brazil". Policy Studies, 36:3, pp.267-282. DOI: 10.1080/01442872.2015.1065970

MENDONÇA, Ricardo Fabrino \& MAIA, Rousiley. (2012), "Deliberation across arenas? Assessing the constitution of general claims about the future of leprosy colonies". In: MAIA, Rousiley C. M. (org.), Deliberation, the media and political talk. Nova York: Hampton Press, pp.287-314.

MENDONÇA, Ricardo Fabrino. (2016), "Mitigating systemic dangers: the role of connectivity inducers in a deliberative system." Critical Policy Studies, v. 10, pp.1-20.

MIGUEL, Luis Felipe. (2013), Democracia e Representação. São Paulo, Editora Unesp.

MIGUEL, Luis Felipe. (2014), "Consenso e conflito na teoria democrática: para além do 'agonismo'”. Lua Nova, v. 92, pp.13-43. 
MIGUEL, Luis Felipe. (2017), Consenso e conflito na democracia contemporânea. São Paulo, Editora Unesp.

MINAS GERAIS, Governo do Estado de \& BRASIL, Governo Federal. (2012), Atas dos Grupos de Trabalho sobre o Parque Nacional da Serra do Gandarela. Belo Horizonte (fac-símile).

MIOLA, Edna. (2012), Sistema deliberativo e tensöes entre interesses públicos e privados: a criação da Empresa Brasil de Comunicação em debate no Congresso e na imprensa. Tese de doutorado em comunicação social. Faculdade de Filosofia e Ciências Humanas da UFMG.

MOUFFE, Chantal. (2005), On the political. Londres e Nova York, Routledge.

MOUFFE, Chantal. (2005), The Democratic Paradox. Londres e Nova York, Verso.

NEBLO, Michael \& WHITE, Avery. (2018), "Politics in Translation: Communication Between Sites of the Deliberative System". In: BÄCHTIGER, Andre; DRYZEK, John; MANSBRIDGE, Jane \& WARREN, Mark (orgs.). The Oxford Handbook of Deliberative Democracy. Oxford, Oxford University Press.

NIEMEYER, Simon \& JENNSTAL, Julia. (2018), "From Minipublics to Deliberative Democracy: Scaling Up Deliberativeness and Subverting Political Manipulation". In: BÄCHTIGER, Andre; DRYZEK, John; MANSBRIDGE, Jane \& WARREN, Mark (orgs.). The Oxford Handbook of Deliberative Democracy. Oxford, Oxford University Press.

PARKINSON, John. (2006), Deliberating in the Real World. Oxford: Oxford University Press.

PARKINSON, John. (2016), "On Scholarly Metaphors, or, What is Deliberative about Deliberative Democracy?" Conference of the European Consortium for Political Research.

PRÓ-CITTÀ, Instituto de Estudos Pró-Cidadania; UFMG, Jardim Botânico da. (2012), "Projeto: Avaliaçáo do patrimônio biológico da Serra do Piaco e identificação de alternativas econômicas sustentáveis nas comunidades adjacentes". Relatório Técnico de Pesquisa. Belo Horizonte.

RANCIÈRE, Jacques. (2005), A partilha do sensivel: Estética e politica. São Paulo, Editora 34.
ROJAS, Claudia Marcela \& PEREIRA, Doralice Barros. (2015), "Políticas e estratégias empresariais de controle territorial: a VALE S. A. e os embates na Serra do Gandarela /MG”. Novos Cadernos NAEA, v. 18, pp.29-49.

ROJAS, Claudia Marcela. (2012), Os conflitos ambientais da Serra do Gandarela na perspectiva das comunidades locais. Dissertação de mestrado em geografia, UFMG.

SCHWARTZ-SHEA, Peregrine \& YANOW, Dvora. (2002), Interpretative Research Design. Londres, Routledge.

SILVA, Eduardo Moreira \& RIBEIRO, Antônio Carlos Andrade. (2016), "Sistemas deliberativos em perspectiva meso: a abordagem dos subsistemas aplicada aos conselhos de políticas públicas em Belo Horizonte". Opiniāo Pública, v. 22, n.1, pp.167-194.

STEVENSON, Harley \& DRYZEK, John. (2014), Democratizing Global Climate Governance. Cambridge, Cambridge University Press.

THOMPSON, Dennis. (2008), "Deliberative Democratic Theory and Empirical Political Science". Annual Review of Political Science, 11:1, pp. 497-520

TRINDADE, Thiago. (2018), "A relação entre protesto e deliberação: reflexôes para o aprofundamento do debate:. Opinião Pública, v. 24, n.1. DOI: 10.1590/1807-019120182411

WARREN, Mark. (2017), "A Problem-Based Approach to Democratic Theory". American Political Science Review 111, 1, pp.39-5.

YOUNG, Iris Marion. (2014 [2005]), "Desafios ativistas à democracia deliberativa". Revista Brasileira de Ciência Política, n.13, pp.187-212.

ZHOURI, Andréa \& VALENCIO, Norma (org.). (2014), Formas de matar, morrer e de resistir: limites da resolução negociada de conflitos ambientais. Belo Horizonte, UFMG.

ZHOURI, Andréa; LASCHEFSKI, Klemens \& PEREIRA, Doralice Barros. (2005), "Desenvolvimento, sustentabilidade e conflitos socioambientais". In: ZHOURI, Andréa; LASCHEFSKI, Klemens \& PEREIRA, Doralice Barros (orgs.). A insustentável leveza da politica ambiental. Belo Horizonte, Autêntica. 


\section{O CONFLITO SOBRE A SERRA DO GANDARELA: UMA ANÁLISE DELIBERATIVA SISTÊMICA}

\section{Filipe Mendes Motta}

Palavras-chave: teoria deliberativa; conflito; sistema deliberativo; Serra do Gandarela

A controvérsia envolvendo a suposta incompatibilidade entre a democracia deliberativa e o conflito tem sido mobilizada para negar as potencialidades dessa vertente. Para reforçar a inexistência dessa dicotomia, partimos da reconstituiçáo de um processo político e buscamos compreender como o conflito contribui para a emergência da deliberaçáo, e, ao mesmo tempo, como a deliberação e a reflexividade são capazes de desencadear o conflito. Nossa análise se debruça sobre o conflito ambiental envolvendo a definiçáo do futuro da Serra do Gandarela, foco de interesses diversos por parte de grupos mineradores, movimento social e população local. A partir de entrevistas com os atores envolvidos, reconstituímos o processo de disputa sobre o futuro da Serra, tendo em mente os diferentes momentos que o compóem. Apontamos como o conflito se manifesta neste contexto e como contribui para a emergência do debate público, a reflexividade dos envolvidos e, em alguma medida, na tomada de decisóes sobre a controvérsia. Apontamos ainda o papel-chave desempenhado pela sociedade civil na costura discursiva do processo, além de chamarmos a ateção para a ação de atores do sistema de justiça como conectores potenciais do sistema deliberativo.

\section{THE CONFLICT ON SERRA DO GANDARELA: A DELIBERATIVE SYSTEMS ANALYSIS}

\section{Filipe Mendes Motta}

Keywords: deliberative theory; conflict; deliberative systems; Serra do Gandarela

The controversy surrounding the supposed incompatibility between deliberative democracy and conflict has been mobilized to deny the potentialities of this theoretical field. To reinforce the inexistence of this dichotomy, we begin from the reconstitution of a political process and seek to understand how conflict contributes to deliberation emergence and, at the same time, how deliberation and reflexivity are capable of triggering this conflict. Our analysis focuses on the environmental conflict involving the definition of the future of Serra do Gandarela, the focus of diverse interests by mining groups, the social movement, and the local population. We reconstructed the dispute process concerning the future of Gandarela from interviews with the involved actors, bearing its different moments in mind. We point out how the conflict manifests itself in this context and how it contributes to the emergence of public debate, to the reflexivity of those involved and, to some extent, in decision-making regarding the controversy. We also point out the key role played by civil society in the discursive binding of the process, while also highlighting justice system actor actions as possible deliberative system connectors.

\section{LE CONFLIT SUR LA SERRA DO GANDARELA: UNE ANALYSE DÉLIBÉRATIVE SYSTÉMIQUE}

\author{
Filipe Mendes Motta
}

Mots-clés: théorie délibérative; conflit; système délibératif; Serra do Gandarela.

La controverse qui entoure la prétendue incompatibilité entre la démocratie délibérative et le conflit a été mise en avant pour nier les potentialités de ce versant. Pour renforcer l'inexistence de cette dichotomie, ce travail part de la reconstitution d'un processus politique afin de comprendre comment le conflit contribue à l'émergence de la délibération, et comment la délibération et la réflexivité peuvent déclencher le conflit. L'analyse porte sur le conflit environnemental qui entoure la définition de l'avenir de la Serra do Gandarela, objet de divergence entre des compagnies minières, un mouvement social et la population locale. À partir d'entretiens des acteurs impliqués, le processus de dispute sur l'avenir de la Serra est reconstitué en tenant compte des différents moments qui le composent. Lobjectif est de montrer de quelle manière se manifeste le conflit dans ce contexte ainsi que sa contribution à l'émergence du débat public, à la réflexivité et, dans une certaine mesure, à la prise de décisions sur la controverse. Enfin, le travail souligne le rôle clé de la société civile dans le tissu discursif du processus et celui des agents du système de justice en tant que connecteurs potentiels du système délibératif. 